\title{
1 UK economic outlook: Emerging from the shadow of Covid-19
}

\author{
by Hande Küçük, Cyrille Lenoël and Rory Macqueen ${ }^{1}$
}

\section{Economic background and overview of the forecast}

Spring optimism gives way to summer caution

The background to our Summer forecast is a period of optimism which has ebbed notably in recent weeks, due to the virulent Delta strain of Covid-19. The UK's advanced vaccination programme has dramatically reduced the link between the virus's spread and mortality, but both deaths and hospitalisations rose noticeably in July. The most recent National Institure Covid-19 Tracker (29 July 2021) indicates a more positive outlook for infection rates since the latest peak.

\section{Figure 1.1 UK daily Covid-19 statistics}

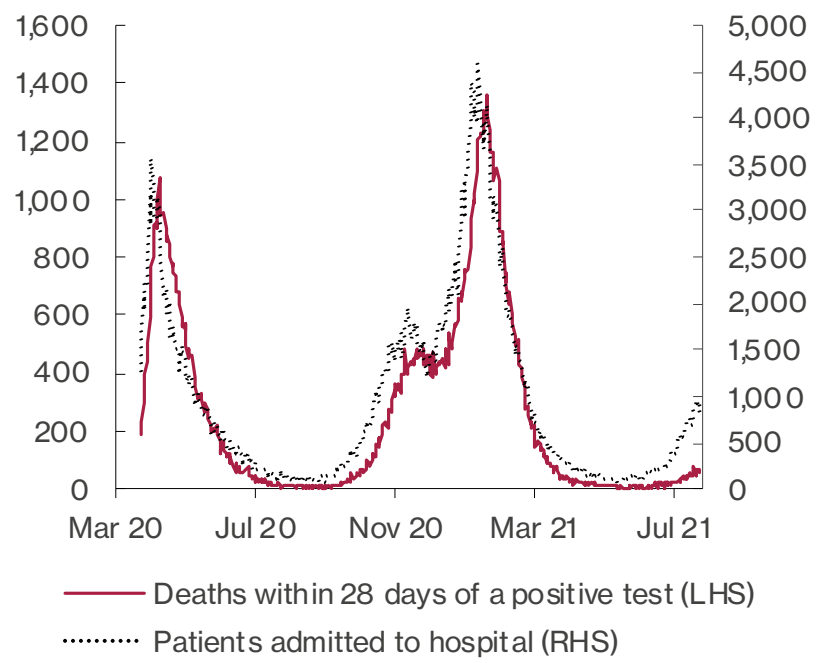

Source: Data.gov.uk

Data indicate more rapid economic growth throughout the second quarter than we forecast in May...

Economic news and indicators until around a month ago were almost universally positive. The fall in GDP in the first quarter of the year was much smaller than that in the second quarter of 2020, suggesting an economy which had learned to deal better with lockdowns. Monthly growth in April was 2.3 per cent while forecasts for 2021 growth rose from 5.7 per cent in April to 7.1 in July. ${ }^{2}$ The FTSE 100 continued its recovery to reach a Covid-era peak in May. Purchasing manager indices set new records.

...but the Delta variant has slowed things and raised questions about prospects for the summer period

Since then the positive message has cooled somewhat, due partly to the natural end of some 'catch-up' effects, but mostly to the renewed growth in Covid-19 cases. Monthon-month growth slowed dramatically in May to 0.8 per cent, of which 0.7 per cent was attributed to the hospitality sector, where restrictions were lifted. Retail sales fell in May and only recovered slightly in June.

The scheduled date for ending remaining restrictions was delayed from 21 st June to 19 th July and the government has advised the public to continue to exercise caution, with a substantial, if lower, degree of voluntary social distancing and mask-wearing still evident. The bond market rallies seen earlier in the year have eased and even reversed slightly (see Figure 1.2) while PMIs have declined from their highs.

Figure 1.2 10-year government bond yields

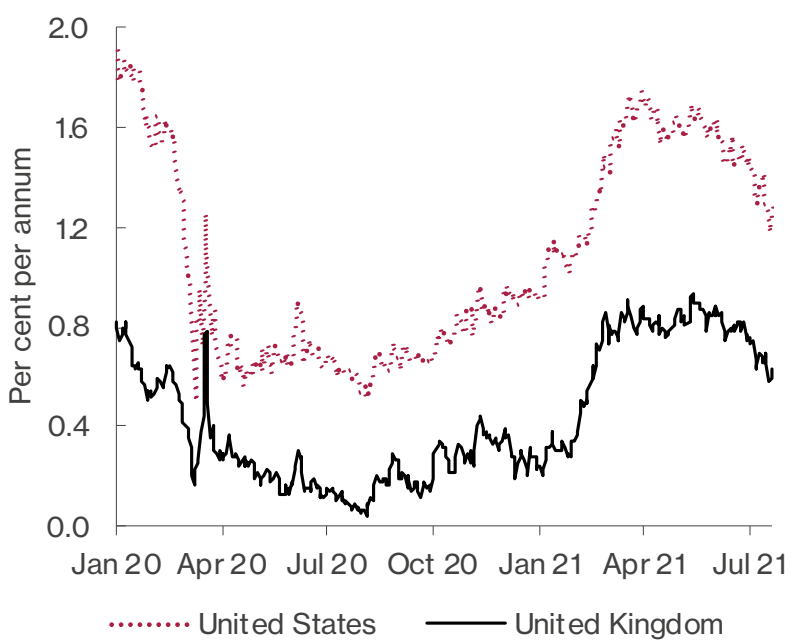

Source: Datastream

1 We would like to thank Arnab Bhattacharjee, Janine Boshoff, Jagjit Chadha, Huw Dixon, Paul Mortimer-Lee, Barry Naisbitt, Andrew Sentance, Bart van Ark and Garry Young for helpful comments and Patricia Sanchez Juanino for preparing the charts and the database underlying the forecast. The forecast was completed on 16th July 2021; more recent data are incorporated in the text. Unless otherwise specified, the source of all data reported in tables and figures is the NiGEM database and NIESR forecast baseline. All questions and comments related to the forecast and its underlying assumptions should be addressed to Cyrille Lenoël (c.lenoel@niesr.ac.uk).

2 As recorded by the 'Average of new forecasts' in HM Treasury's monthly 'Forecasts for the UK economy' 
Construction and re-opened sectors grew strongly in the first half of the year and the prospects for domestic tourism look good

As seen in Figure 1.3, debit and credit card spending peaked in May at around 100 per cent of pre-Covid levels but has eased slightly since then. EPC certificates for housing construction reached very high levels in the first quarter before falling back. Job vacancies continue their secular rise, with shortages widely reported. According to the Office for National Statistics, the fastest quarterly growth rates were in sectors emerging from restrictions: hospitality and arts and recreation, closely followed by real estate activities.
One area where Covid-19 continues to cause enormous disruption is the international travel industry. In 2018 inbound foreign tourism was worth $\$ 48.5$ billion to the UK economy, while UK tourists were responsible for $\$ 68.9$ billion of spending abroad. Both are likely to be severely curtailed and there is a high degree of uncertainty but if the reduction of flows in each direction is proportional there is the potential for a boost of several billion pounds to domestic tourism this year, something likely to be further aided by the loosening of restrictions on vaccinated US and EU travellers. Anecdotal evidence suggests that this is also feeding through into higher prices for holiday accommodation.

Figure 1.3 Office for National Statistics (ONS) spending and hiring indicators

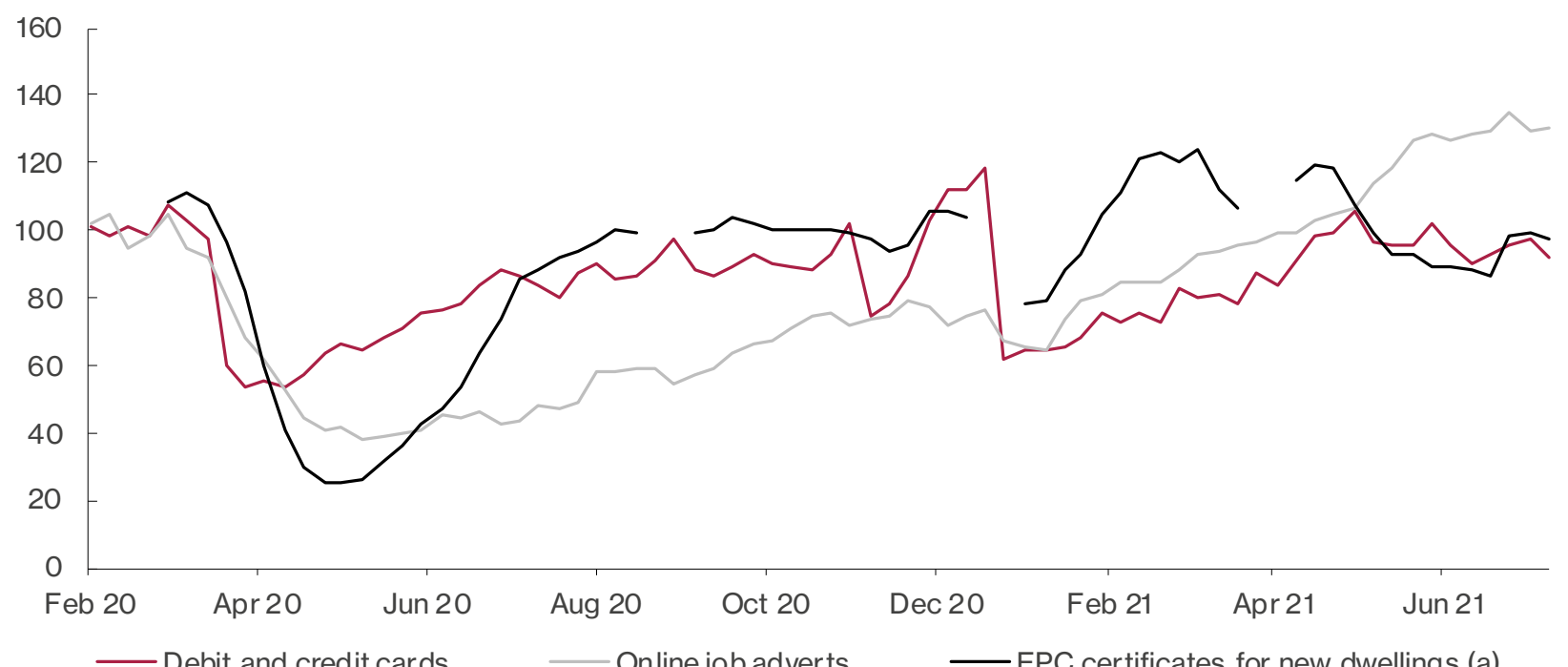

(a) England and Wales.

Debit and credit cards (CHAPS-based): 100 = February 2020, percentage change on a backward looking seven-day rolling average, non-seasonally adjusted, nominal prices. Job adverts: 100 = the same week in 2019. EPC certificates: change from the same week in 2019/2020, four-week rolling average, adjusted for timing of holidays.

Source: ONS, BoE, Adzuna, MHCLG, NIESR

Faster growth in Q2 has raised the level of GDP for the rest of the year, leading to a strengthening of our growth forecast for 2021

We have revised up our forecast for GDP growth in the UK this year from 5.7 per cent to 6.8 per cent, reflecting the general strengthening of economic conditions which has taken place since our Spring Economic Outlook. Despite the slowing of the rate of increase, there remains substantial capacity in the economy to be recovered as business and consumer confidence return. We assume that domestic economic conditions continue to improve steadily, with only foreign travel restrictions remaining by the end of the year. The possibility of further outbreaks constitutes the largest downside risk to all elements of our forecast.
Rising inflation will erode some of the gains from faster growth but is expected to peak in the first half of 2022 ... Consumer price inflation is forecast to rise through the year, reaching 3.5 per cent in the final quarter before peaking at 3.9 per cent in the first quarter of next year. We expect continuing strong demand growth in the sectors which are re-opening, alongside supply problems in some of these sectors but also others, such as manufacturing, less affected by the re-opening 'boom'. Inflation's rise to almost two percentage points above target reflects this, as well as base effects from the slow growth of prices at the start of the pandemic and the return of VAT to 20 per cent in the hospitality sector, and is likely to be transitory (See Box A). 
Figure 1.4 Sectoral balances (saving minus investment)

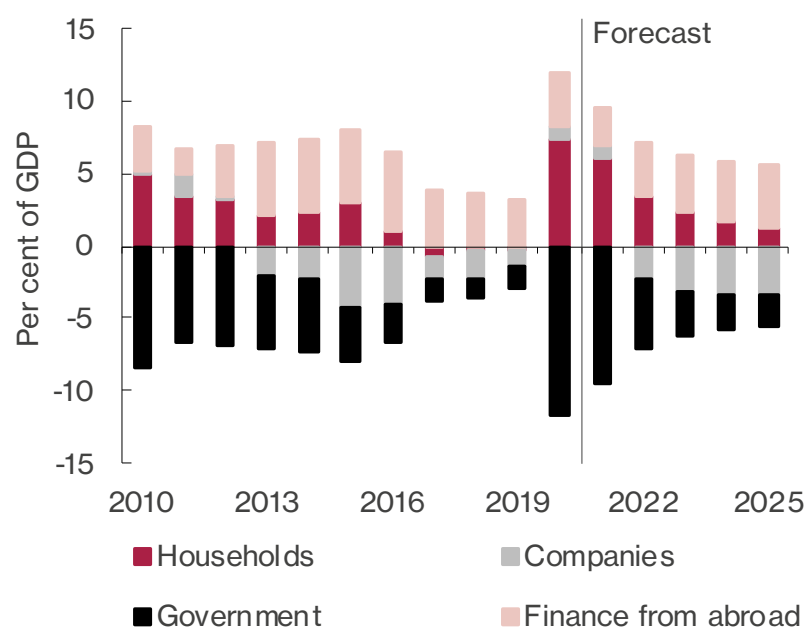

Source: NiGEM database, NIESR forecast

...though interest rates are not expected to rise until late 2022

We forecast Bank Rate to remain at its current level until the fourth quarter of 2022 in line with market expectations. The Monetary Policy Committee's future communications around tapering asset purchases and policy rate normalisation will be crucial to keep inflation expectations well anchored while preventing a destabilising reaction from financial markets (see Box B).

Household income growth looks strong thanks to workers returning from furlough

Household incomes are forecast to rise by over 5 per cent this year, with average earnings growing by 2.4 per cent. Unemployment peaks at 5.4 per cent in the last quarter of 2021, after the Coronavirus Job Retention Scheme comes to an end, consistent with around 150,000 people not returning to their furloughed job or finding another during or after the third quarter.

Public debt peaks next year after the withdrawal of Covid-19 fiscal support

Government borrowing remains relatively high this year at around 8 per cent of GDP, so that government debt climbs in 2022-23 to just below 99 per cent of GDP, falling to 92 per cent by $2025-26$.

The current account deficit returns to pre-referendum levels in the medium term

We forecast the current account deficit to shrink this year but to remain around 4 per cent in the medium term (see Figure 1.4). Domestically, the reduction in government borrowing is matched by the reduction in household saving and the return of the corporate sector to positive net investment.
Figure 1.5 Projected quarterly growth in 2021

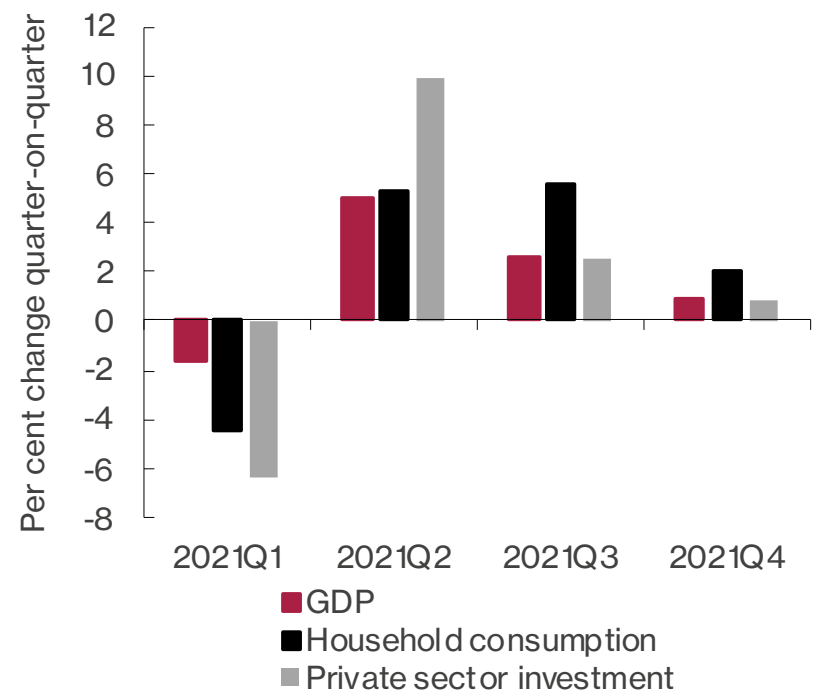

Source: NiGEM database, NIESR forecast

Note: Household consumption is household and NPISH final

consumption expenditure (durable and non-durable).

\section{Economic activity}

Spring growth was faster than anticipated but the Delta variant has meant a downside risk being realised In our UK forecast for the Spring Economic Outlook we forecast growth of 5.7 per cent for the UK economy in 2021 , faster than at any time in living memory but with significant downside risk from the emergence of new variants of Covid-19: something which has materialised in the form of the Delta variant.

Much economic data since then has been positive, and our GDP forecast has been revised up accordingly, but not by as much as might have been the case a month ago.

Both demand and supply are likely to be affected by the resurgence of the virus at a time when we hoped it would be largely in the past

With high frequency indicators and surveys indicating a slowing of growth in the middle part of the year, it seems that demand in many sectors is growing more slowly than would have been the case in the absence of a resurgence in Covid-19 infections, due partly to the delay in lifting restrictions but also to consumer hesitancy. Hopefully, the success of the vaccination programme and a fall in hospitalisations will translate into a full recovery for consumer-facing services which comes slightly later but is no weaker than would have been the case. 
This has coincided with the rise of certain supplyside constraints: a widely-reported global shortage of semiconductors which is expected to ease; supply chain bottlenecks, in particular relating to imports from the European Union; and a shortage of labour exacerbated by compulsory Covid-related isolation but concentrated in sectors which previously relied on European workers and those in age-groups not yet fully vaccinated. The last of these constraints is only likely to be exacerbated, along with the supply restrictions inherent to social distancing, by any renewed spread of Covid-19.

\section{Output in several sectors remains well below pre-Covid peaks}

As discussed in previous UK forecasts the initial Covid-19 shock was a sectorally and regionally heterogenous one, with face-to-face service sectors - and areas with economies which centre around those sectors - badly affected, but also construction and manufacturing. By the third quarter of 2020 output was over 11 per cent lower than a year earlier in the West Midlands, compared with around 3 per cent in Northern Ireland. Subsequent waves have been more concentrated in terms of their impact, with the largest effects on education, hospitality, arts and recreation in the first quarter of 2021.

Figure 1.6 GDP fan chart (quarterly, 2018 prices)

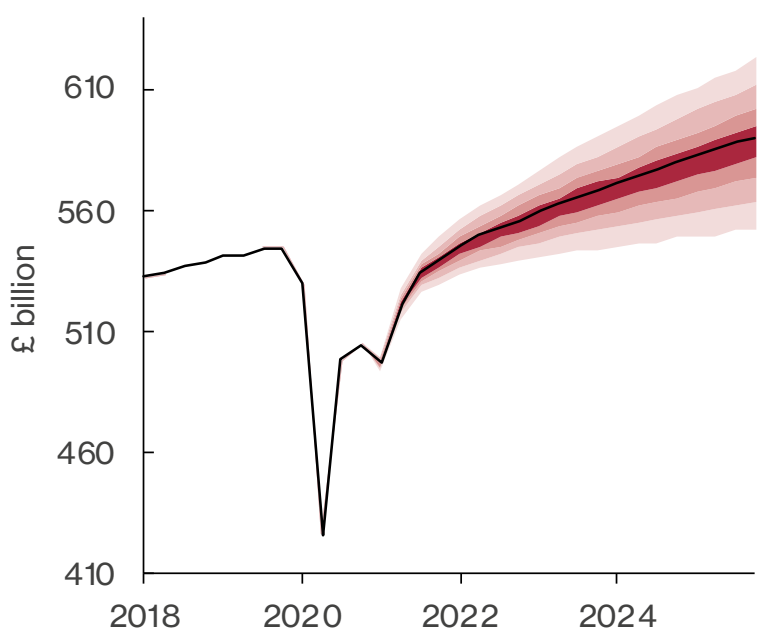

Source: NiGEM database, NIGEM forecast, NIGEM stochastic simulation.

Notes: The fan chart is intended to represent the uncertainty around the main-case forecast scenario shown by the black line. There is a 10 per cent chance that GDP growth in any particular year will lie within any given shaded area in the chart. There is a 20 per cent chance that GDP growth will lie outside the shaded area of the fan chart.
Unsurprisingly, monthly GDP data in Spring suggested the fastest growth rates in sectors which saw their Covid-19 restrictions lifted: the hospitality sector was operating at around 40 per cent of its February 2020 peak during the first quarter of the year, returning to around 80 per cent in May, but still suffering from both reduced consumer demand and reduced labour supply. Clearly, substitution took place while hospitality outlets were closed: the retail sector offsetting losses in non-essential shops during lockdown with increased sales of food and drink. April saw retail and wholesale activity 5 per cent above its pre-Covid peak, falling slightly in May as some spending switched back to pubs and restaurants.

The manufacturing sector has been badly hit by global shortages of equipment, which are expected to ease in the third quarter, and is likely to have seen around zero growth in the second quarter. Construction had a strong first quarter, possibly responding to rising house prices, and the finance sector recovered its February 2020 level a year later, seemingly not too badly affected by the lack of an equivalence agreement with the European Union or the loss of trading to other European cities.

Fast growth in the second quarter has raised our forecast for this year and next

We estimate that GDP grew by around 5 per cent in the second quarter of 2021 and will slow to 2.6 per cent in the third quarter - still rapid by historical standards - on the assumption of waning Covid-19 cases and the lifting of all domestic restrictions by the end of the third quarter (Figure 1.5). This leads to forecast growth for 2021 of 6.8 per cent in 2021 year-on-year.

In our main case forecast scenario GDP then grows by 5.3 per cent in 2022 and 2.4 per cent in 2023, returning below 2 per cent in 2025. This means that GDP will supersede its pre-Covid peak from the final quarter of 2019 in the first quarter of 2022 (see Figure 1.6), but the forecast trajectory remains around 3 per cent lower than its pre-Covid trend. Over the six years from 2020 to 2025 the cumulative loss in GDP, relative to a continuation of the 2010-2019 trend, is forecast to be $£ 735$ billion. Cumulative growth of 8 per cent between 2019 and 2025 is comparable to other major European economies but slower than the US.

The combination of Brexit and Covid-19 is likely to lead to permanent scarring to the level of GDP, though not its growth path

Our forecast for GDP in 2025 is now 2 per cent lower than we forecast in February 2020, at a time when we knew the outline of the government's Brexit deal but Covid-19's effects on the UK were not understood. One of the main channels of scarring from the pandemic is weaker capital accumulation due to lockdowns, prolonged pandemic uncertainty and financial factors including increased indebtedness of small and medium-sized enterprises (see Box C). The long-run effects of Brexit due to a reduction in trade and foreign direct investment flows are likely to reinforce the long-run effects of the pandemic. 
A second channel is related to the effects of Covid-19 on labour supply. Even if lockdown restrictions are relaxed, the pandemic will still have restraining effects due to the need for self-isolation. The reduction in migration also implies a smaller labour force, which affects potential output in the long run. Weaker capital accumulation and continued disruptions in labour supply due to reoccurring waves of infection are also likely to reduce labour market productivity although permanent working from home arrangements and increase in digitalisation and automation may mitigate these effects (Van Ark et al, 2020 and Haskel, 2021).

Figure 1.7 Forecast growth in 2021

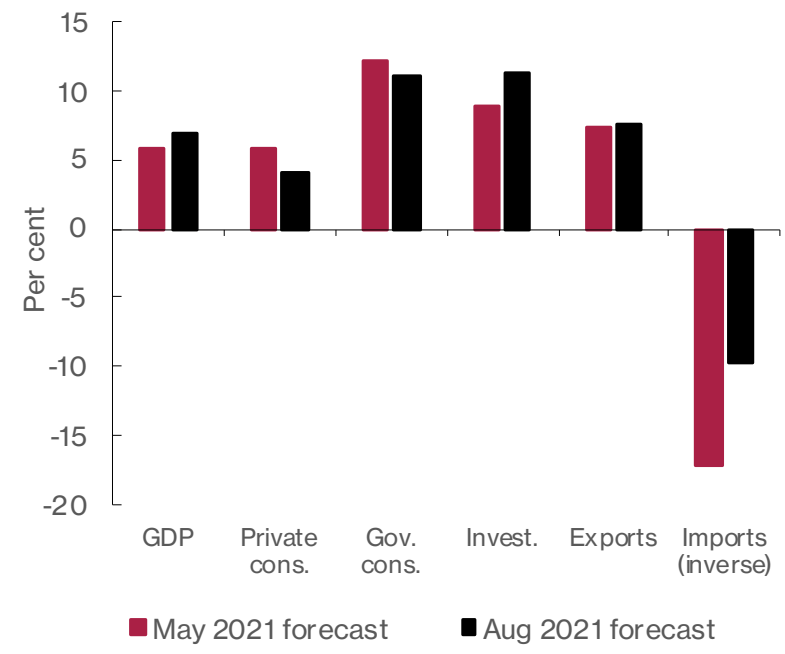

Source: NIESR forecast

Figure 1.8 Components of investment growth

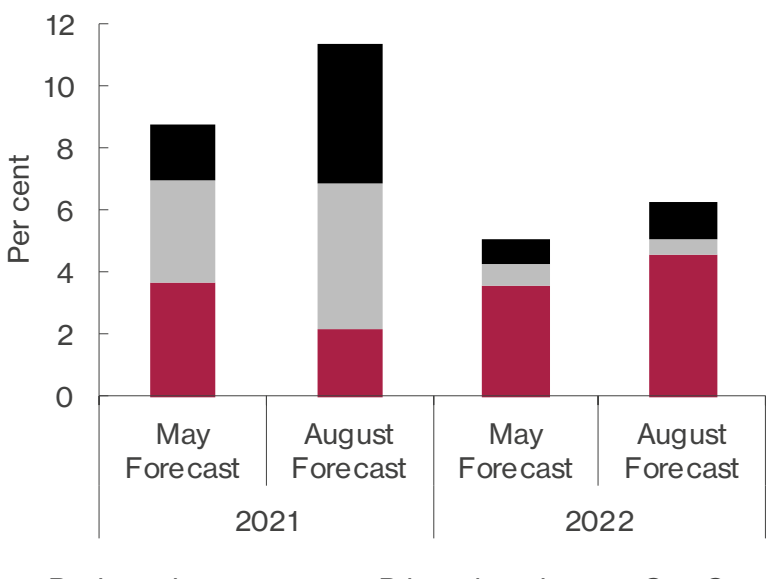

- Business investment $\quad$ Private housing $\square$ Gen Govt.
Investment and the trade position are expected to provide greater support to 2021 growth

As seen in Figures 1.7 and 1.8, growth in 2021 is now expected to be boosted more by investment than was our view in May, though this is principally due to government and housing sector investment, with business investment recovering more strongly in 2022. Net exports are also expected to make a greater positive contribution, less due to an increased demand for UK exports than a reduction in imports (see page 17).

Risks to GDP are evenly balanced. Upside risks to GDP come, as in our Spring Outlook, from the faster running down of consumer savings, a rapid normalising of behaviour following full vaccination, and business confidence leading to a boom in investment. Downside risks come from uncertainties regarding the pandemic and the increase in cases related to the Delta variant, with unknown consequences for consumer confidence.

Manufacturing growth is limited by supply shortages with growth mostly coming from services

Using our sectoral model, NiSEM (see Lenoël and Young, 2021), we forecast GVA in construction to have the fastest growth rate in 2021, with output increasing by 14 per cent after a similar fall in 2020 (see Table A11). Private nontraded services, which include hospitality, retail, arts and recreation, fared the worst in 2020 - falling by 15 per cent - and are now forecast to grow by 9 per cent this year and next. Manufacturing is forecast to grow by 6 per cent this year after a 10 per cent fall in 2020 . Unsurprisingly the mining and quarrying sector sees a large decline, reflecting both the scheduled maintenance to oil platforms which began in April and the long-term reduction in fossil fuel extraction from the UK continental shelf. As seen in Figure 1.9, sectors that contracted the most in 2020 are expected to display larger increases in 2021, reflecting the effects of opening-up and an element of catch-up.

Relatively weak growth in the manufacturing sector (with sectoral GVA expected to recover to its pre-pandemic level by the second half of 2022) will have material spillovers onto other sectors. While the manufacturing sector has a relatively small share in total gross value added, its share of gross output is much higher, reflecting its greater use of intermediate goods and services produced in other sectors. 
Figure 1.9 Sectoral growth in 2020 and 2021

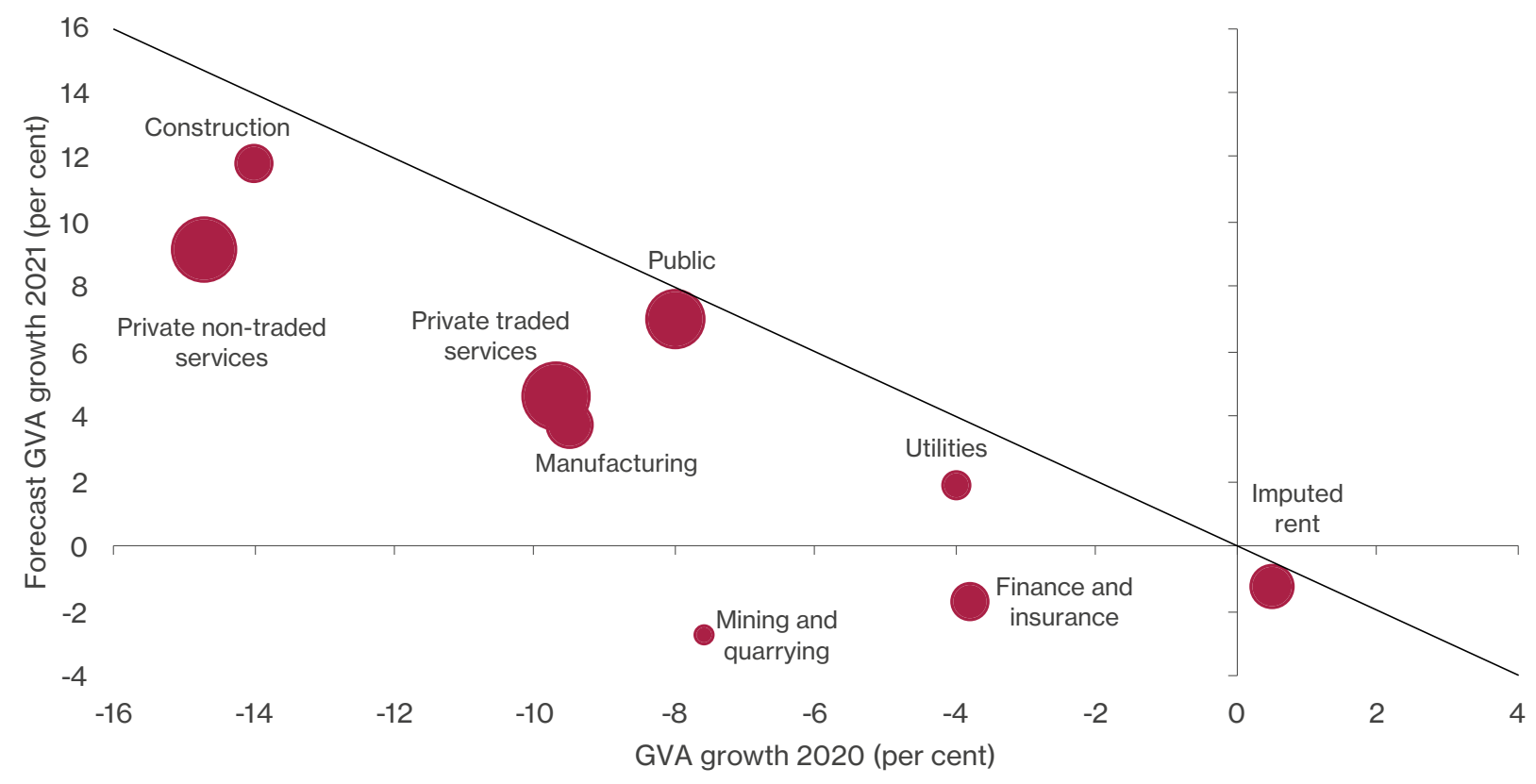

Source: NiSEM forecast

Note: Size of bubbles is proportional to sector GVA. The diagonal line indicates equal-sized fall in 2020 and rise in 2021.

\section{Households}

Winter lockdown brought a record drop in consumption and a surge in 'forced savings'

Household consumption declined more than expected in the first quarter, by 4.4 per cent after falling by 1.6 per cent in the last quarter of 2020, because of the new lockdown. This represents the second largest quarterly fall since 1961 , after the 20.9 per cent decline in the second quarter of 2020. According to Bank of England research (Franklin et al, 2021), in March 2021 the middle three income quintiles reported the largest falls in spending, compared with 2020 when the top three quintiles recorded the largest reductions.

Real personal disposable income declined more moderately in the first quarter, by 0.9 per cent, due to the loss of income for employees on furlough. The savings rate increased in the first quarter to 20 per cent, the second highest level since 1961, after reaching 25 per cent in the second quarter of 2020.

But consumption will rebound strongly in the rest of the year and reach its pre-pandemic level in the first quarter of 2022

Starting in the second quarter, we forecast a strong rebound in consumption driven by the lifting of restrictions and improved consumer confidence. The GfK Consumer Confidence Index in July returned to its pre-pandemic level. Retail sales, a key component of consumption, surged when retail shops reopened after the winter lockdown, and in May were 8.8 per cent higher than in May 2019, representing an annual growth rate of 4.3 per cent over two years (see Figure 1.10). Spending on credit and debit cards saw an even larger increase though in the week to 15 July remained at 92 per cent of the February 2020 average.

Figure 1.10 Retail sales

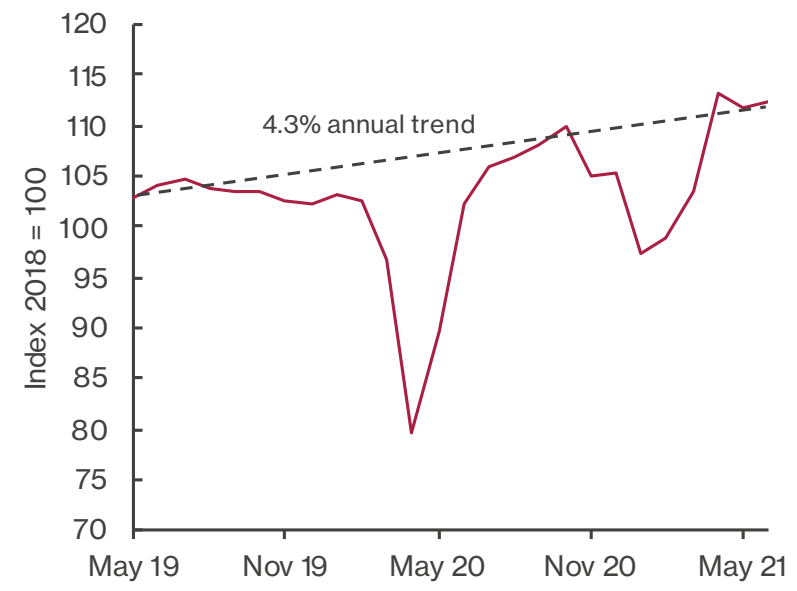

Source: ONS, Retail sales index for Great Britain 


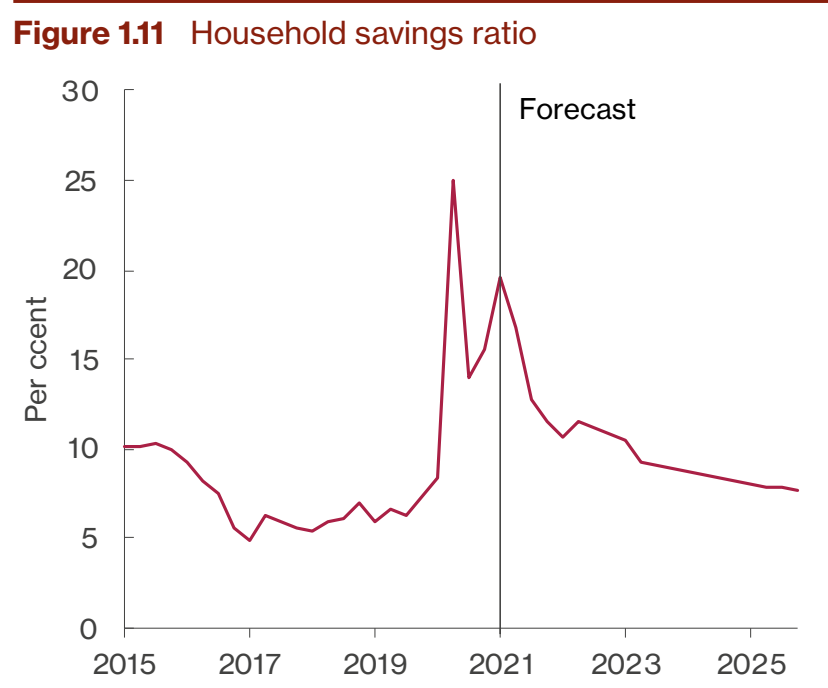

Note: NiGEM database, NIESR forecast

Figure 1.12 Decomposition of fall in employment since February 2020: decline in economically active, increase in unemployment

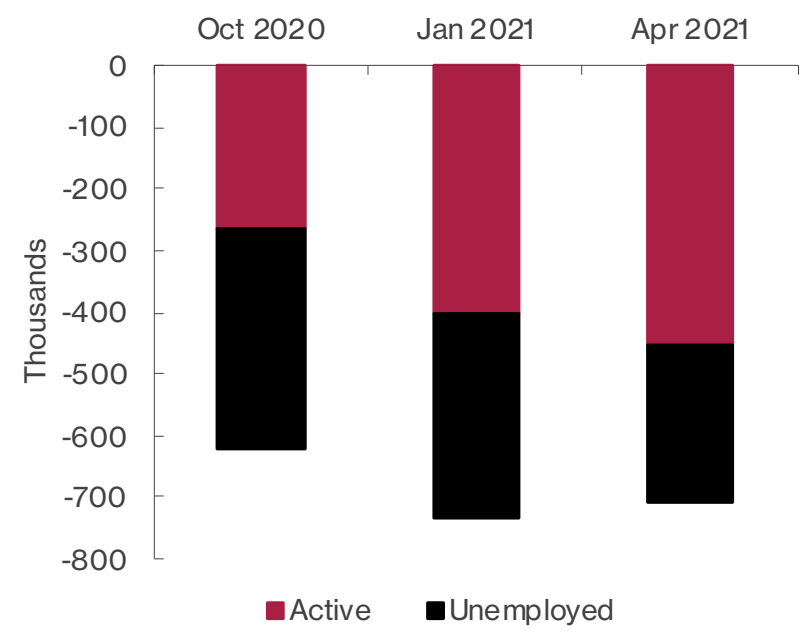

Source: ONS

Thanks to a drawdown of some 'forced savings', consumption is forecast to return to its pre-pandemic level in the first quarter of next year. As a result the savings rate progressively returns to around 8 per cent at the end of the forecast period, close to its 1997-2019 average of $81 / 2$ per cent (Figure 1.11).

Employment fell during the pandemic because people dropped out of the labour force

Since the beginning of the pandemic, Labour Force Survey employment has declined by 706,000. Most of this decline can be attributed to people dropping out of the labour force, rather than a rise in unemployment: Figure 1.12 decomposes the decline in employment since February
Figure 1.13 (Mis)match between vacancies and furlough by sectors

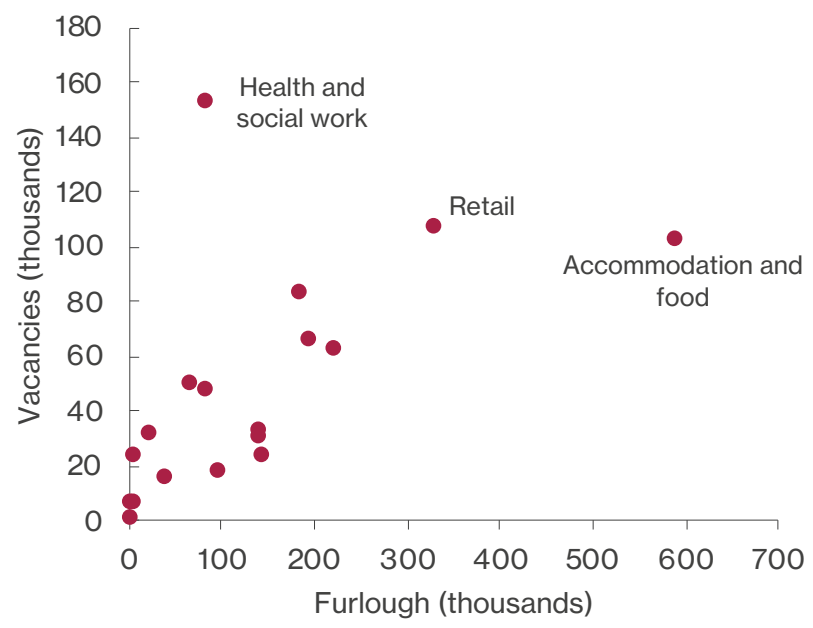

Source: ONS and HMRC. Vacancies are for June and furlough for end of May.

2020. In April, the number of economically active people was 455,000 fewer than in February 2020, while the number of unemployed increased by 252,000 over the same period. Chapter 2 provides a detailed analysis on labour force decomposition across UK regions.

Some of the reduction in the active labour force is explained by people becoming inactive - for example to look after their family - and some by people leaving the country to return to their home country - a large fraction of this being EU citizens. In our main case scenario, we follow the ONS population projections and do not yet expect this reduction in the labour force to be permanent. This obviously constitutes a downside risk to our forecast.

Labour shortages in health and excess labour in accommodation

The end of the furlough scheme in September will force businesses to re-evaluate their labour needs in the next few months. The number of workers on furlough nearly halved from 5.1 million in January to 2.5 million at the end of May thanks to the partial lifting of restrictions but the rapid fall in furlough has not been enough to accommodate the recovery in labour demand, and vacancies increased to a record level of 862,000 in the three months to June. A stock of 1.9 million workers still on furlough at the end of June suggests that there is room for employers to respond to further increases in business activity by taking back workers that were on furlough, but there is a risk of a mismatch between the sectors that are hiring and the skills of the people in furlough.

Figure 1.13 compares vacancies and furlough by sectors: two sectors stand out. On the one hand, the health and social work sector shows a clear shortage with nearly twice as many vacancies as people still on furlough. On the other hand, the accommodation and food services sector 
seems to have excess labour with nearly six times as many furloughed workers as vacancies. There are also reports of labour shortages in haulage.

Unemployment to peak at 5.4 per cent after the end of the furlough scheme

While headline unemployment stood at 4.8 per cent in March to May 2021, if all full-time furloughed staff were included (analogous to how furloughed staff are reported in the US) the unemployment rate would have been 8-9 per cent. Using a rule-of-thumb Okun's Law coefficient of $0.4^{3}$, GDP 7 per cent below pre-Covid trend for the second quarter would imply an unemployment rate of 6.5-7.0 per cent. On the other hand, a Beveridge Curve estimated on the period 2007-2019 would associate the number of vacancies with an unemployment rate below 4 per cent.

We have revised down our unemployment forecast because of the unexpected rise in employment during the winter lockdown and reported labour shortages in some sectors. Unemployment is now set to peak at 5.4 per cent in the fourth quarter of 2021, a full percentage point below our previous forecast peak (Figure 1.14). This is consistent with around 150,000 of those on furlough being added to the official unemployment figures between the third and fourth quarters.

\section{Figure 1.14 UK unemployment}

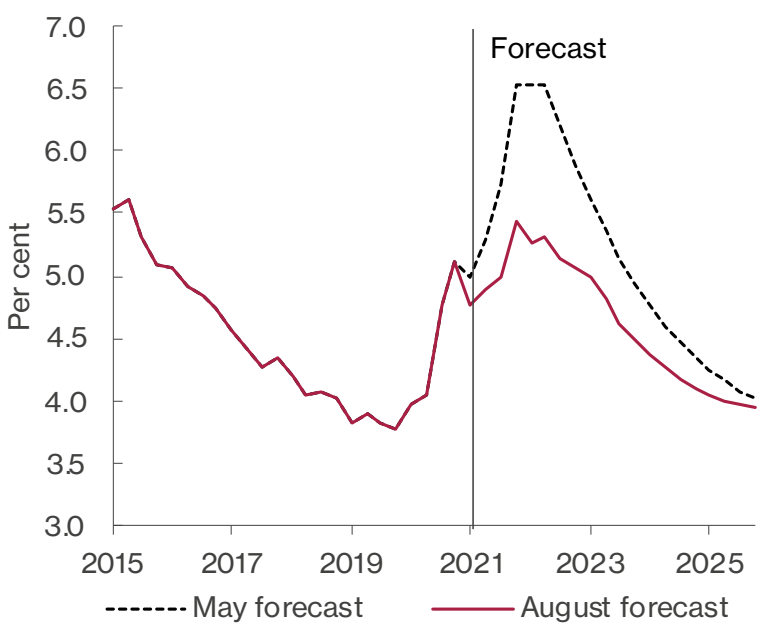

\section{Earnings growth is expected to this year}

Growth in average weekly earnings including bonuses in Great Britain increased sharply in the three months to May to 7.3 per cent, compared to a year ago, up from 5.7 per cent in the three months to April. Removing the effects of a low base last year - caused by the drop in earnings by workers on furlough - and from a change in the earnings distribution with lower-paid workers dropping out, the National Institute Wage Tracker in July estimated that underlying earnings growth was 3.8 per cent in the three months to May, up from 2.5 per cent in the three months to April. We forecast growth in earnings of 2.4 per cent this year and 5.2 next year.

The KPMG and REC UK Report on Jobs points to a decrease in candidate availability to explain the rise in wages, in particular for new recruits. The end of the furlough scheme in September should increase candidate availability and reduce pressure on wages, but relatively strong wage growth could continue if there is a persistent mismatch between the skills of the labour force and the demand of new jobs.

...but the rise in inflation will limit real income gains Real personal disposable income is expected to increase by 2.8 per cent this year after having declined by 0.6 per cent last year. The gradual return of employees from furlough and the increase in wages in sectors that suffer labour shortages are the main reason for the household income gains, but an expected rise in inflation this year and next will limit the real income gains.

House price growth is set to moderate next year after government support ends

HM Land Registry's house price index increased by 10 per cent in the year to May, the fastest growth rate since 2007. The rise in house prices can be explained by a combination of temporary and more permanent factors. The increased popularity of working from home has pushed people to spend more on housing, while last year's reduction in property taxes is being reversed this year (the Stamp Duty holiday in England will expire in October). As government support is removed, we expect house prices to moderate from a growth of $71 / 2$ per cent this year to $1 \frac{1 / 2}{2}$ per cent next year.

3 Taken from Prof. Jonathan Haskel's 19 July remarks 'Will the pandemic “scar” the economy?' https://www.bankofengland.co.uk/speech/2021/ july/jonathan-haskel-speech-on-scaring-in-the-economy-at-the-university-of-liverpool 


\section{Firms}

Business confidence is high, with credit ample and demand expected to be strong...

Business confidence indicators have hit record highs in recent months. The Lloyds Business Barometer reported monthly increases in trading prospects and employment expectations in each of the five months to June. UK equities (see Figure 1.15) reached a Covid-era high in spring but remain below their early 2020 peak. The Bank of England's credit conditions survey reported a slight improvement in the availability of credit to the corporate sector in the second quarter, concentrated in credit for large firms, with little change expected in the third quarter.

Anecdotally, participants at NIESR's quarterly Business Conditions Forum ${ }^{4}$ reported that while firms were hesitant about hiring new staff due to demand conditions a year ago, hiring is now constrained by the supply of labour. There has been speculation about the extent to which this is driven by lower migration, lower vaccination rates amongst young workers and the continuation of the furlough scheme. A downside risk to demand-side optimism is clearly constituted by the recent uptick in Covid-19 cases discussed on page 6 .

...but limiting factors are emerging on the supply side Healthy demand expectations are being joined as a source of inflation upside risk by input costs faced by firms. Continued Covid-related restrictions on capacity, including social distancing, may be imposed by government or voluntarily adopted by businesses in order to reassure consumers: to this extent the persistence of the virus constitutes a threat to the supply side as well as the demand side.

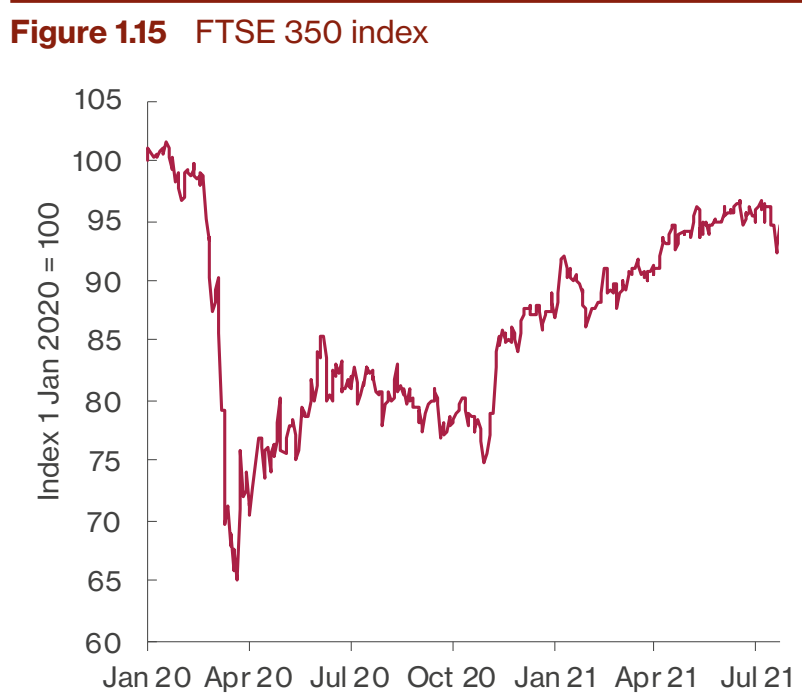

Source: DataStream, NIESR calculations

Many firms are carrying increased debt as a result of Covid-19 but they appear to be concentrated in sectors with the strongest outlooks for 2020

For many firms increased input costs in the medium-term future will include the servicing of debt acquired over the past 18 months. Government-guaranteed loan schemes have been used by one in four businesses. Businesses in the sectors which were worst affected by Covid-19 - hospitality, arts and recreation - were more likely to have used the CJRS

Figure 1.16 Sector shares of output and Covid-19 government loans

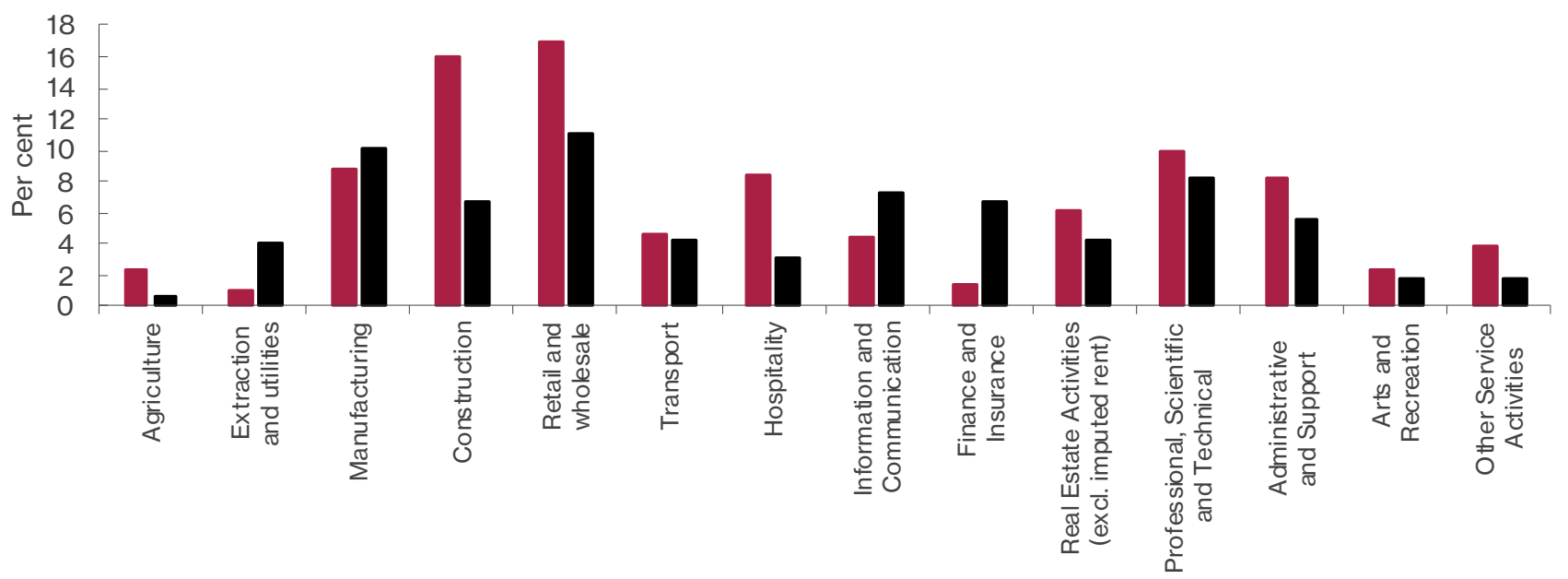

Share of to tal loans value

Share of GVA (2019Q4)

Source: British Business Bank, NIESR calculations. Predominantly non-market sectors (education, health and public administration) excluded.

4 See www.niesr.ac.uk/summary-niesr-business-conditions-forum 
than loan schemes (Banks et al, 2021), no doubt because in relative terms their need for support was greater than their confidence in being able to repay any loans. Corporate debt acquired during Covid-19 and likely implications for investment are discussed in Box C.

Figure 1.16 shows that around a third of loans were issued to firms in the retail and construction sectors, which are among those to have already recovered relatively strongly. Bank of England agents reported in Q2 that concerns about corporate failures were receding, though risks remained in areas such as foreign travel and businesses based in office districts. Taken together with the distribution of loans, it seems likely that the majority of repayments will fall on firms in sectors which have grown healthily so far in 2021 and may be well placed to pass on any increased costs to consumers.

Business reports strong investment intentions but a very weak start to 2021 will impact annual growth figures

Business investment fell by more than 10 per cent in the first quarter of 2021 to 17 per cent below its pre-Covid level: a much larger decrease than the economy as a whole. Healthy growth from this low base appears likely, given the optimism reported in business surveys and the end to Brexit-related uncertainty. The Accenture/IHSMarkit UK Business Outlook reported in July that capital expenditure and $R \& D$ plans were the highest for six years.

We forecast business investment to increase by only 4 per cent this year, held back by the large fall in the first quarter, but to rise by 9 per cent in 2022. Private housing investment recovers more quickly, rising by 18 per cent this year after a 13 per cent fall in 2020 . Overall we forecast investment to rise by 11 per cent this year, supported by a 24 per cent rise in government investment (see Figure 1.8 on page 10$)$.

The private capital stock is forecast to rise by slightly above 1 per cent on average annually between 2022 and 2025, compared with around 4 per cent in the public sector.

\section{Productivity}

There was considerable sectoral heterogeneity in labour productivity growth in $\mathbf{2 0 2 0}$

Labour productivity, as measured by GDP per hours worked, rose by 0.4 per cent in 2020 , with substantial sectoral heterogeneity as output and hours responses to the pandemic varied significantly across sectors. Figure 1.17 shows the breakdown of hourly productivity growth by five major sectors, i.e. agriculture, manufacturing, construction, finance and insurance, and services excluding finance and insurance, to highlight sectoral differences in labour productivity due to Covid-19.

\section{Figure 1.17 Annual growth in labour productivity (per cent)}

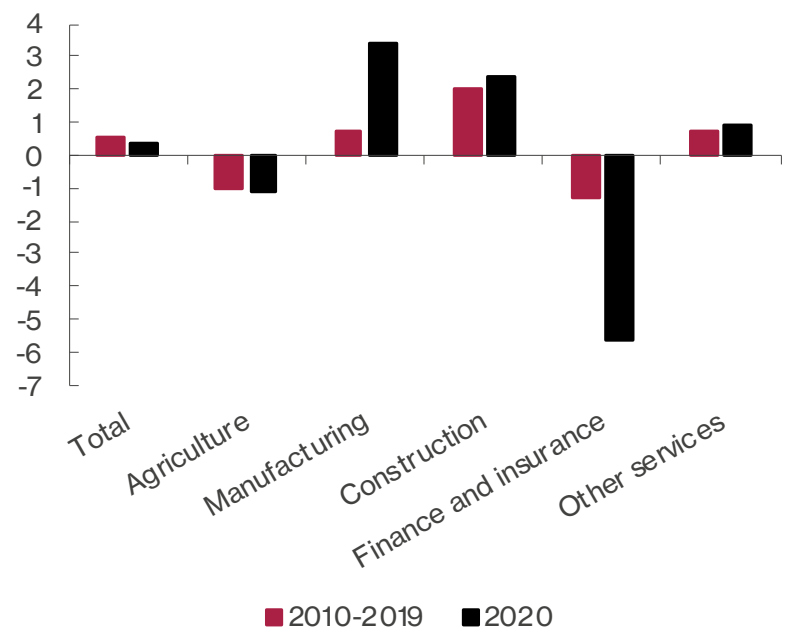

Source: ONS

Lockdown restrictions during 2020 meant that total hours worked fell in all major sectors, except within finance and insurance, where remote or teleworking was most commonly a feasible alternative to face-to-face work. Interestingly, hourly productivity in the manufacturing sector increased by 3.4 per cent during the pandemic, posting a growth rate almost five times its post-GFC growth rate of 0.7 per cent. The growth rates of hourly productivity in construction and services (2.3 and 0.9 per cent respectively) were more in line with their post-GFC averages while finance and insurance posted a big fall $(-5.7$ per cent) in hourly productivity. 


\begin{abstract}
Allocation effects have supported the rise in labour productivity both at sector and at aggregate level

Part of the increase in hourly productivity seen in 2020 reflects allocation effects i.e. a shift of production from lower productivity firms toward higher productivity ones (see Figure 1.18), though manufacturing sector hourly productivity increased by around 2 per cent.
\end{abstract}

Figure 1.18 Contributions to productivity growth

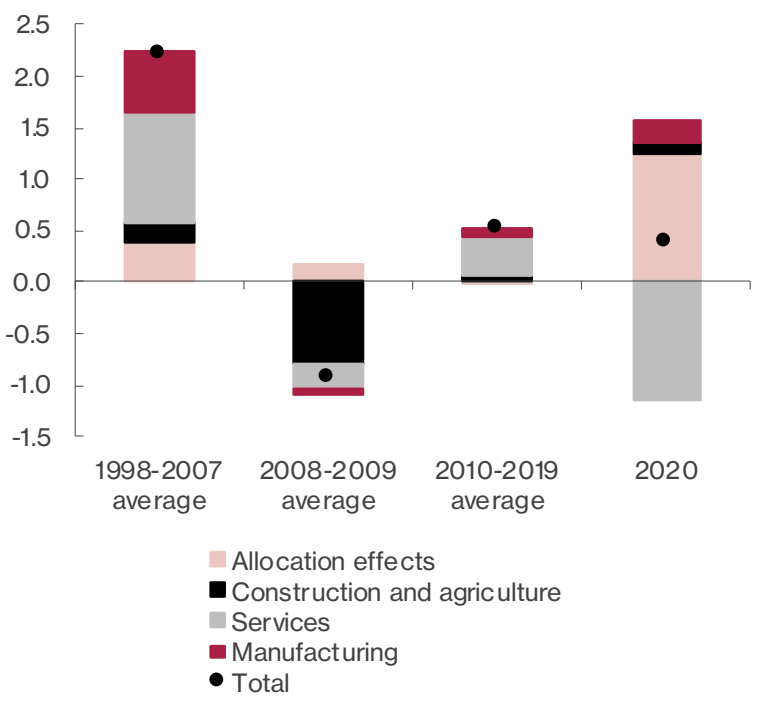

Source: ONS, NIESR calculations

As the economy re-opens, it is anticipated that less productive firms will resume trading and therefore temper the observed rise in overall productivity. Although the data is likely to be subject to large revisions in the near future (ONS, 2021), productivity rises may also partly be reflecting accelerated use of new technologies including digitisation and automation, as firms adjusted to the pandemic.

Our main-case scenario envisages 1 per cent growth in labour productivity in the medium term but with significant downside risks

Labour productivity increased by 0.8 in the first quarter of 2021 as hours worked dropped more than GDP during the winter lockdown. Our main-case scenario is for labour productivity to grow by 0.7 per cent in each of 2021 and 2022 as the economy normalises. We forecast a higher rate of labour productivity growth from 2023, averaging 1 per cent a year between 2023 and 2025, implying sustained positive effects from the acceleration in digital transformation during the pandemic (discussed in Van Ark, 2021).

However, there are significant downside risks; for example, productivity gains may be concentrated in already highperforming businesses with limited spillover effects for the rest of the economy, and investment in $R \& D$ and new technologies might be weaker due to deteriorated balance sheets or persistent demand deficiencies.

The statistical adjustment for double deflation is likely to lead to revisions in our labour productivity forecasts following the publication of quarterly productivity estimates consistent with Blue Book 2021 in October 2021. On one hand, the implementation of double deflation implies a slightly stronger trend for labour productivity growth after the Global Financial Crisis, which is likely to be reflected in medium-term forecasts. But it might also imply a downward revision to growth in the short-term due to a base effect if the present level of productivity is revised up significantly.

\section{A permanent increase in home working may have small consequences for productivity \\ Research about the impact on productivity of an increase in home-working remains inconclusive. On average, workers in the UK report being as productive as they were pre-pandemic. There may be productivity gains for jobs which are better suited, and workers who have previously worked at home, but reductions in productivity have been reported for others (see Marioni, 2021).}

\section{Trade}

Imports account for the majority of the fall in expenditure at the start of the year

In the first quarter of 2021 UK gross final expenditure GDP plus imports - fell by almost $£ 30$ billion (in constant 2018 prices). However, after the removal of expenditure on imports, which fell by over $£ 20$ billion, the reduction in GDP was less than $£ 10$ billion. Given that renewed Covid restrictions were concentrated in service sectors with low import intensity (hospitality, transport, education and retail), the dramatic fall in imports is unlikely to have been principally driven by the new lockdown. Indeed, the decrease was much larger for trade with the EU than with the rest of the world, and much larger in goods than services. $£ 11$ billion of the $£ 15$ billion decrease in goods imports from the EU was in chemicals, materials, machinery and transport equipment: not commodities obviously linked to lockdown.

Brexit disruption accounts for the lion's share of the fall in the first quarter and imports from the European Union have struggled to recover since January

Total trade (exports plus imports) with the European Union fell by 22 per cent in the first quarter of the year, compared with a 4.5 per cent fall in trade with the rest of the world, suggesting that Brexit was having a large effect. Some of this reflects the natural unwinding of the temporary increase in UK-EU trade which occurred at the end of 2020, driven by uncertainty about the coming change. Temporary 'teething problems', such as new 
paperwork and customs checkpoints, have also played a role but are being gradually reduced. ${ }^{5}$

Figure 1.19 shows the evolution of import and export volumes since the start of 2020 relative to the same month in 2018, the last year before the UK's first planned exit from the EU and the Covid-19 pandemic both affected monthly trade figures. Imports from both the EU and elsewhere suffered in Spring 2020, during the UK's first and largest national lockdown, but the fall in January 2021 (and slow recovery) is much more evident in imports from the EU. Synthetic control methods by UK Trade Policy Observatory (Tamberi, 2021) find UK exports to the EU 42 per cent below counterfactual in January and still down by 14 per cent in April, while imports fell by less initially but more persistently: over 25 per cent down on a counterfactual scenario. This could be because of greater problems with new paperwork on the UK side of the border, a decrease in demand for EU-produced products, or even substitution of non-EU suppliers in supply chains.

Figure 1.19 UK imports and exports

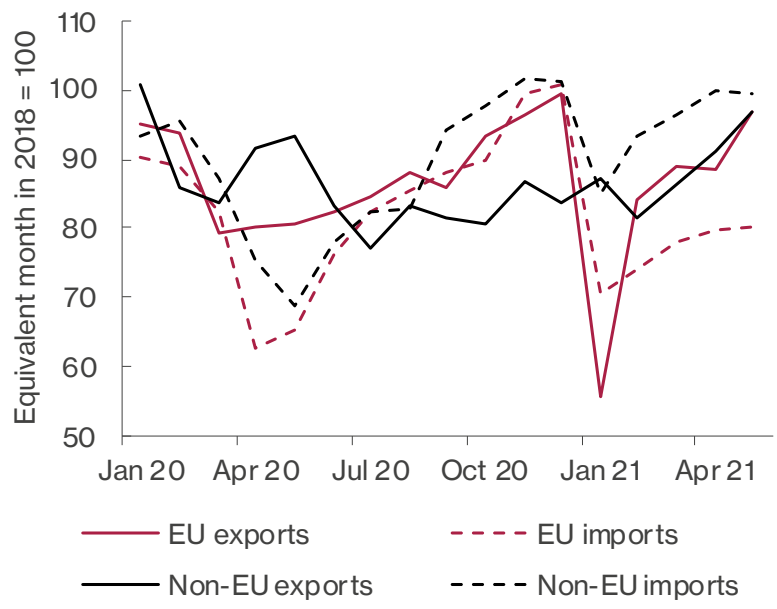

Source: ONS, NIESR calculations

Relatively supportive sterling conditions should have limited the cost to importers of price rises in Europe and the rest of the world

Sterling's appreciation since the start of the year ought to have helped importers offset rising input costs, so weak imports are not driven by price movements. The volatility of trade data means that it may nonetheless be some time before we can answer with certainty how much of the shift is permanent, how much has been compensated by trade with the rest of the world, how much by increased domestic production and how much by reduced expenditure.
The restrictions placed on international travel are likely to impact on exports and imports in the third quarter particularly, as discussed on page 7, resulting in less crossborder economic activity. Over the medium-term export volumes are forecast slightly higher, due to stronger global demand. In our central case forecast scenario the current account deficit narrows further to 2.5 per cent of GDP this year, returning to around 4 per cent of GDP for the majority of the forecast period. The effective exchange rate is expected to remain around its current level between now and 2025.

\section{Fiscal policy}

The deficit was lower in 2020-21 than previously expected...

The budget deficit for financial year 2020-21 was slightly lower than expected, at $£ 299$ billion or 14.2 per cent of GDP, compared to $£ 322$ billion, or 15.6 per cent of GDP in our May forecast. The downward revision can be explained by lower managed expenditure and slightly higher receipts.

\section{...but fiscal stimulus continues into 2021-22}

Covid-related fiscal stimulus is continuing into the current financial year, with, for example, lower Value Added Tax rates in hospitality and tourism. Borrowing in the first two months of 2021-22 came to $£ 53.4$ billion, lower than the $£ 91.1$ billion in the first two months of 2020-21 when the government initiated extraordinary support at the beginning of the pandemic, but higher than the $£ 11.9$ billion seen in $2019-20$. We have revised down our forecast for public sector borrowing to $£ 194$ billion or 8.2 per cent of GDP in 2021-22, compared to 9.6 per cent of GDP in the May forecast, mainly as a result of higher receipts on the back of stronger GDP growth.

\section{The super-deduction will have limited macroeconomic} effects

The current tax deduction on investment in plant and machinery (the 'super-deduction' announced at the Budget in March) is forecast to help business investment back towards pre-pandemic levels, but we do not forecast a sustained investment boom as the end of the deduction in March 2023 and higher corporation tax thereafter reduce the expected earnings from investment.

\section{Government debt peaks at close to 100 per cent of GDP in 2022-23}

Sustained fiscal consolidation is expected to increase in 2022-23, with the headline corporation tax rate being increased from 19 to 25 per cent in 2023. The March Budget also includes downward revisions to the departmental spending envelope ahead of the expected Spending Review and reports since have suggested a tough

5 Since the start of the year Eurostat data have recorded lower exports from the UK to the EU than UK data, due to methodology changes, with no corresponding difference in imports data. Research suggests that HMRC/ONS data are more accurate and should be used for comparison: see Gasiorek, M. and Tamberi, N. (2021) 'Trade data statistics', University of Sussex Business School Working Paper 09-2021 
spending round: see Box D for a discussion of the impact of the reduction in government spending on foreign aid in 2021 .

Figure 1.20 Public sector net debt

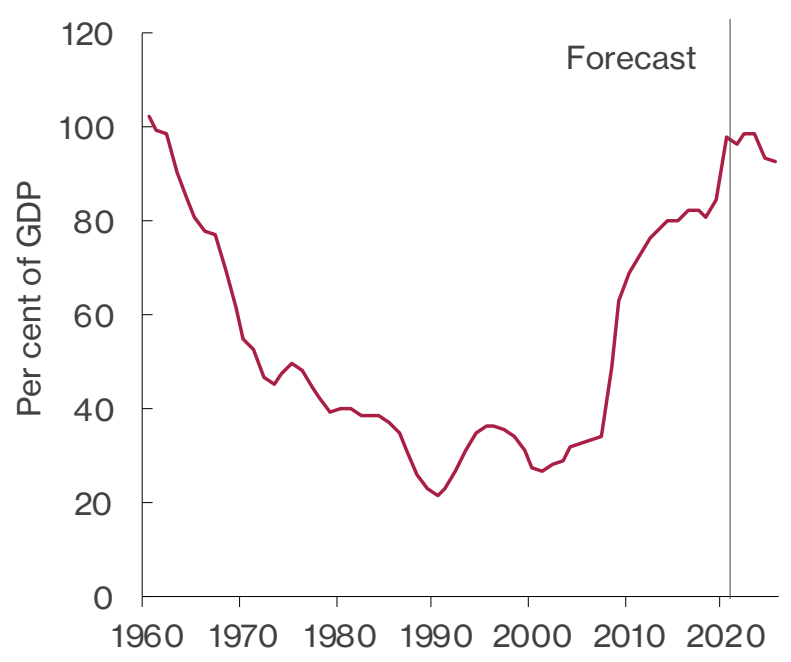

Source: ONS, NIESR forecast

Public sector net debt stood at $£ 2.2$ billion in May and is still increasing due to the relatively high level of borrowing. The debt stock has risen from around 80 per cent of GDP before the pandemic to close to 100 per cent (Figure 1.20). We expect the recovery in GDP and the reduction in public spending to slow this rise to 96.4 per cent at the end of 2021-22 and 98.6 per cent in 2022-23.

Debt is forecast to decline as a share of GDP thereafter, partly thanks to the assumed end of the Term Funding Scheme. The fall of 1.4 percentage points in 2025-26 suggests that additional public investment in excess of $£ 30$ billion would be compatible with a stable debt-toGDP ratio. As described in our Spring Economic Outlook, preparing for future shocks to public health (or reducing the risk of catastrophic climate change) has economic benefits in the longer term which may outweigh the shortterm benefit from reducing public debt.

Debt interest payments decline as a share of GDP despite the recent rise in inflation

The increase to our inflation forecast this year and next leads to higher debt interest payments both through indexlinked gilts and higher interest rate forecasts but, even taking this into account, debt interest payments decline in our main case scenario from 2 per cent of GDP in 2020 to 1.9 per cent this year and 1.8 per cent next year. This is an upward revision from our May forecast of 1.5 per cent of GDP this year and next (see Figure 1.21).

Figure 1.21 UK government debt interest payments

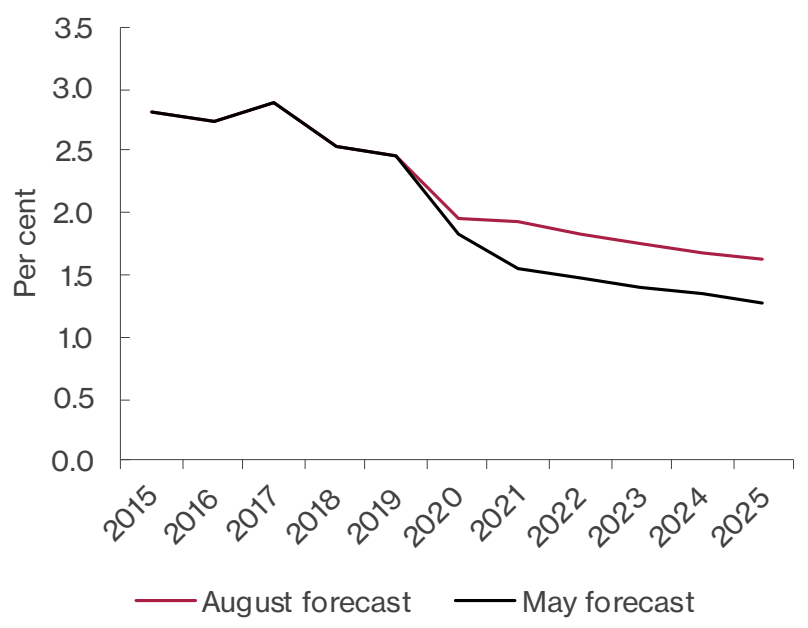

Source: NiGEM database, NIESR forecast

Government debt interest is more sensitive to Bank Rate rises but these are likely to be offset by increased tax receipts from higher GDP

Quantitative easing has reduced the cost of servicing debt because the Bank of England pays interests to the Treasury on the gilts it holds. This has however made debt interest payments more sensitive to changes in short-term interest rates because it has reduced the average maturity of public sector net debt (which includes Bank of England holdings).

Higher than expected inflation that triggers a monetary policy tightening by increasing interest rates or reducing QE may constitute a risk to the fiscal forecast but, as explained in Macqueen (2021), an increase in debt interest payments is not a concern when occasioned by a rise in real GDP, because government revenues also rise. Upward revisions to inflation also aid the fiscal position through fiscal drag while both nominal and real gains lead to a larger denominator for the debt/GDP ratio. 
Figure 1.22 Contributions to annual CPI inflation in June 2021

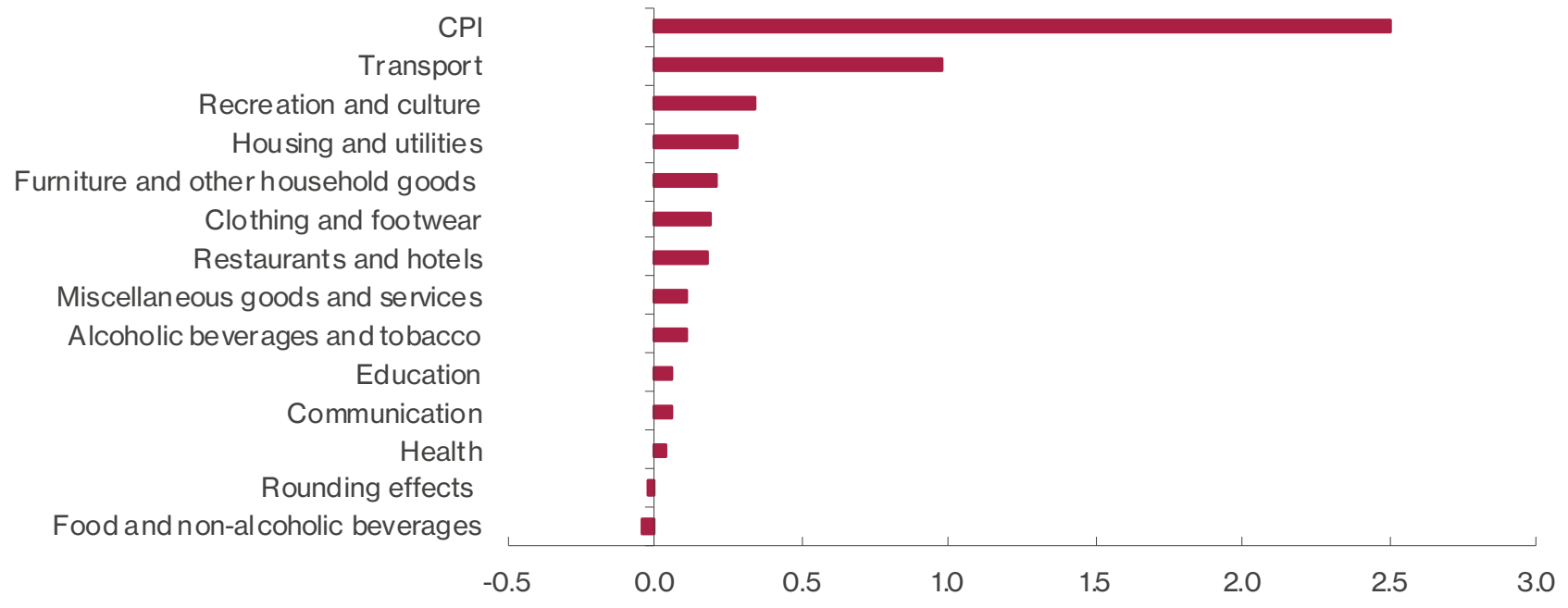

Source: ONS

\section{Inflation and monetary policy}

\section{Annual consumer price inflation displayed a sharp rise} in the second quarter of 2021

Annual headline inflation has increased steadily during the second quarter, rising from 0.7 per cent in March to 2.5 per cent in June - the highest level recorded in almost three years. Underlying inflation measured by the trimmed mean (which excludes 5 per cent of the highest and lowest price changes) has also moved up, increasing from 0.6 per cent in March to 1.6 per cent in June (see National Institute Monthly CPI Tracker, July 2021).

Low inflation during the first lockdown, the surge in oil prices and price increases in reopening sectors all played a role...

Although a low base from the lockdown period of last year plays a part in the rise in annual headline inflation, relatively high month-on-month inflation rates recorded in the second quarter were a larger factor (see discussion of "drop-in" and "drop-out" inflation in Box A). Average month-on-month inflation, 0.05 per cent between March 2020 and March 2021, shot up to 0.58 per cent in the second quarter.

Higher oil prices reflected in transport prices and the effects of reopening in some sectors such as eating out and retail clothing contributed to the notable rise in inflation in the second quarter. Figure 1.22 shows that, by June 2021, about 1 percentage points of annual headline inflation came from transport and a total of 0.7 percentage points from restaurants and hotels, recreation and arts and clothing.
Figure 1.23 UK annual inflation

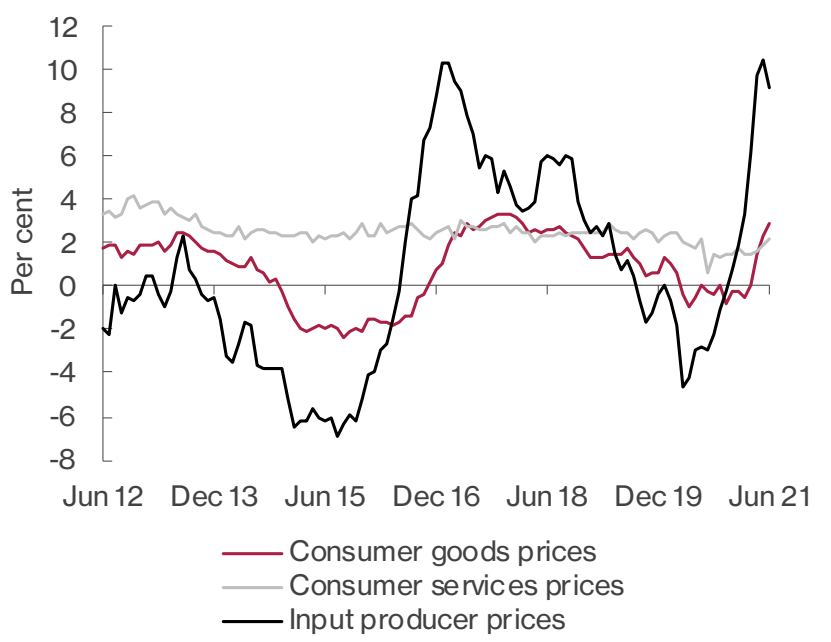

Source: ONS

...but due to producer cost pressures price increases have been widespread in consumer goods prices

In addition to the effects of higher oil prices and reopening, reported shortages in intermediate inputs and ongoing supplier delays have filtered through to consumer goods, making the increase in consumer prices more widespread. Despite the sterling appreciation in the first two quarters of 2021, annual inflation in producer input prices, negative for most of 2020, has sharply risen since the start of the year, reaching 10.4 per cent in May and easing to 9.1 per cent as of June. The volatility in producer price inflation has been reflected in goods price inflation, while services inflation has remained more stable (Figure 1.23). As producer prices affect consumer good prices with a delay, relatively high levels of good price inflation may 
persist in the short term before starting to come down as disruptions to supply chains ease.

The rise in consumer inflation will continue in the short-term, with a likely peak in the first quarter of 2022

Supply-side factors and the effects of reopening which have dominated the recent surge in inflation are likely to keep inflationary pressures high in the short-term. The recovery in aggregate demand will also contribute to higher inflation through increased capacity utilization rates. Base effects will continue to add to the volatility in inflation in the coming months, having a notable downward effect in July and September but an upward effect in August. The VAT cut of 2020 is scheduled to be reversed in October 2021 and April 2022, which will add to the upward pressure on annual consumer price inflation depending on the degree of pass-through (See Box A).

Figure 1.24 Expectations of annual inflation

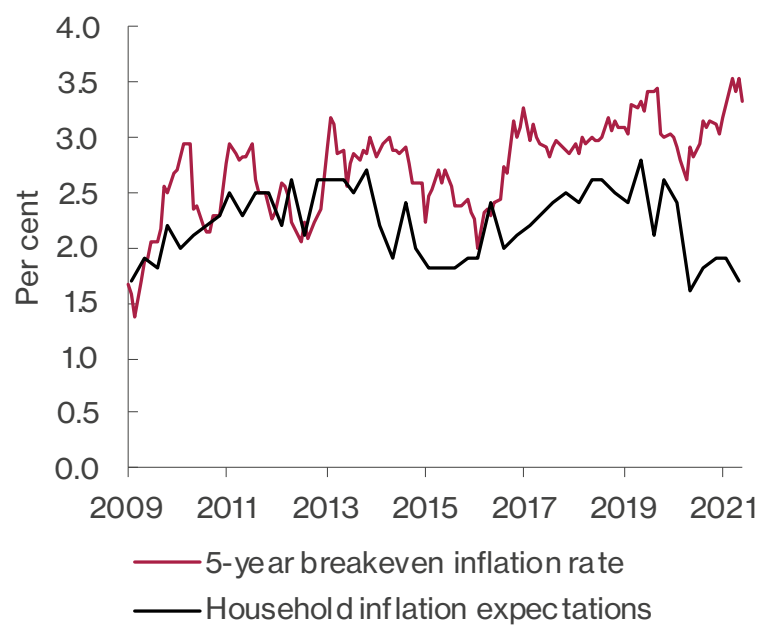

Source: Bank of England, Resolution Foundation, NIESR calculations

Notes: Household expectations are based on Inflation Attitudes Survey, financial market expectations are based on 5-year break even inflation rates.

Our main-case inflation forecast is conditional on policy rates rising in the last quarter of next year

As a result, in our main-case scenario, we forecast CPI inflation to rise to 3.5 per cent in the last quarter of the year, peaking at 3.9 per cent in the first quarter of 2022 but falling again to settle around 2 per cent in 2023 (see Figure 1.25). The removal of temporary factors such as rising VAT for certain sectors and the pass-through from higher input prices will be instrumental in the forecast fall over the rest of 2022, i.e. base effects working in the opposite direction. However, this forecast is conditional on policy rates starting to be normalised in the last quarter of next year (in line with market expectations), and inflation expectations remaining well-anchored, limiting possible secondary effects from supply-side factors, which are assumed to be temporary.

Dislodged inflation expectations and stronger demand side recovery are the main upside risks to inflation Although inflation expectations have not yet displayed any notable rise (Figure 1.24), annual inflation is expected to remain above target for most part of next year, which could lead to dislodging of expectations, posing an upside risk to our inflation forecasts for next year and beyond. A stronger than expected recovery in consumption, possibly led by a faster unwinding of accumulated savings, also constitutes an important upside risk, which could imply inflation remaining above the 2 per cent target beyond 2022 (Figure 1.25).

To be alert to the potential for transitory inflation effects becoming more persistent, a number of indicators should be monitored over the coming weeks and months: underlying wage growth after adjusting for base and compositional effects; market and household expectations for future inflation; firm mark-ups; and any sign of contagion from sectors experiencing temporarily high inflation (see Figure 1.22 and Dixon, 2021) to the rest of the economy.

Figure 1.25 Inflation fan chart

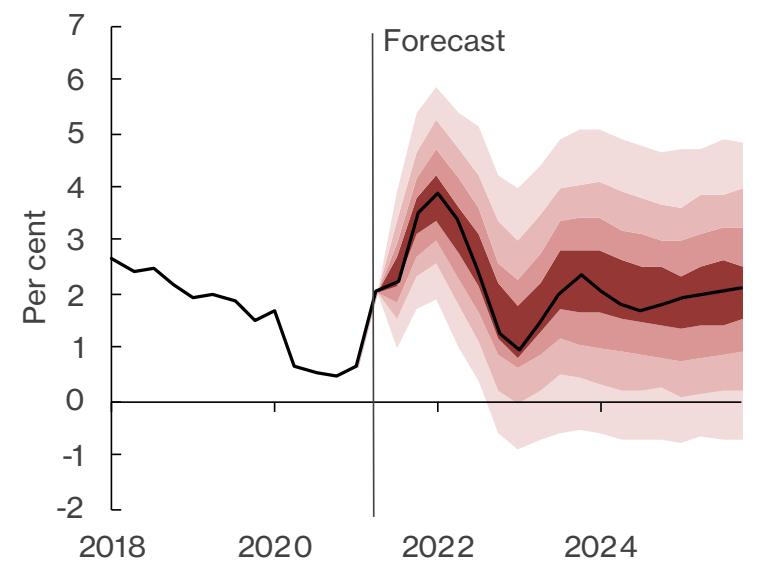

Source: NiGEM database, NIGEM forecast, NIGEM stochastic simulation

Notes: The fan chart is intended to represent the uncertainty around the main-case forecast scenario shown by the black line. There is a 10 per cent chance that CPI inflation in any particular year will lie within any given shaded area in the chart. There is a 20 per cent chance that $\mathrm{CPI}$ inflation will lie outside the shaded area of the fan. The Bank of England's CPI inflation target is 2 per cent per annum. 
Figure 1.26 Bank of England policy rate

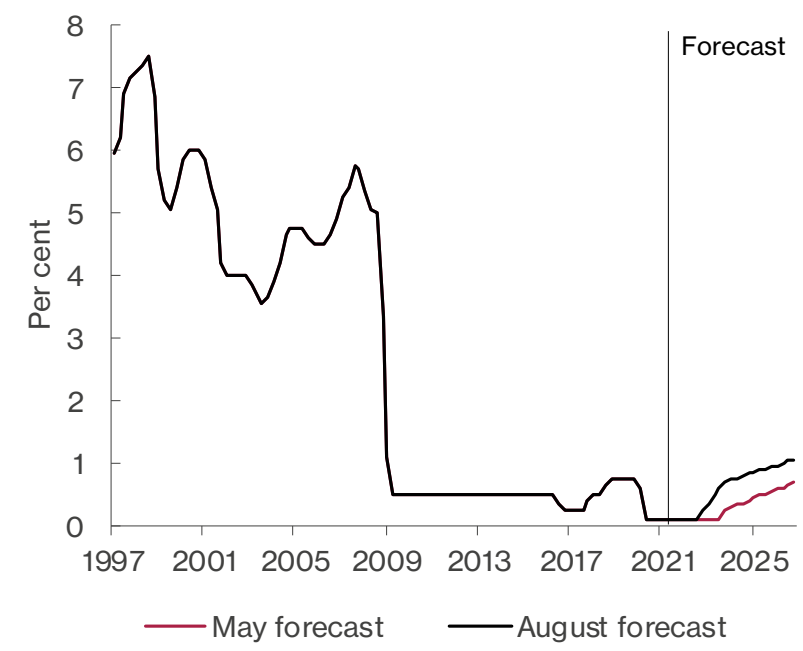

Source: NiGEM database, NIESR forecast

We recommend that the Bank of England starts preparing the ground for normalising its monetary policy stance by clearly communicating how Bank Rate and asset purchases will be adjusted in response to a changing inflation outlook

Both the main-case scenario and the balance of risks around it suggest that the Bank of England's priority should be to keep inflation expectations well anchored around the 2 per cent inflation target in order to prevent the forecast rise in short-term inflation from feeding into a wage and price spiral, making the increase more permanent. In line with market expectations at the time of the forecast, we anticipate the first rise in Bank Rate taking place in the fourth quarter of 2022.

As we have emphasised previously (see Barwell, 2021, and Chadha, 2021) the Bank of England ought to give more guidance as to the timing and instrument of monetary policy tightening to contain inflation expectations. A change in the Bank's communication to signal a tighter stance conditional on the persistence of inflationary pressures beyond the transitory effects, and the announcement of a plan for tapering asset purchases when required, might help start monetary policy normalisation without causing a significant tightening in financial conditions which risks the ongoing recovery from the pandemic.
Bank of England communication around tapering and policy rate normalisation will be crucial to avoid a significant tightening in financial conditions

Although quantitative easing (QE) programmes have a significant impact in lowering government bond yields (Rossi, 2021), there is considerable uncertainty regarding their effectiveness across different states of the economy, the strength of their transmission channels and their interaction with the policy rate, especially when a normalisation of the monetary policy stance is required. As Bailey (2020) argues, to the extent that QE is more effective during crisis periods, there might be a stronger case for relying more on balance sheet unwind during normalisation, but there is little prior experience with tapering asset purchases and the effects of the unwind on long-term yields through the portfolio rebalancing and signalling channels remain uncertain. Hence, the Bank of England needs to communicate any taper plan very carefully, including its implications for future path of policy rates, in order to avoid overreaction from financial markets (Box B provides a discussion of the literature on different aspects of unwinding $\mathrm{QE}$ ). 


\section{REFERENCES}

Bailey, A. (2020), 'The central bank balance sheet as a policy tool: past, present and future', Paper prepared for the Jackson Hole Economic Policy Symposium, 27-28 August 2020

Banks, W., Karmakar, S. and Walker, D. (2021) 'What types of businesses have used government support during the Covid-19 pandemic?', Bank Underground, 5 July

Barwell, R. (2021), 'MPC communication: the case for taking back control of financial conditions', May 2021, UK Economic Outlook, Spring 2021 issue.

Chadha, J.S (2021), Written evidence submitted to the Quantitative Easing Inquiry by Economic Affairs Committee https://committees.parliament.uk/writtenevidence/36897/ $\mathrm{html} /$

Dixon, H. (2020), 'Will CPIH inflation understate inflation for April 2020?,' NIESR blog https://www.niesr.ac.uk/blog/willcpih-inflation-understate-inflation-april-2020

Dixon, H. (2021) 'CPI Inflation, June 2021', NIESR blog, 14 July

Franklin, F., Green, G., Rice-Jones, L., Venables, S. and Wukovits-Votzi, T. (2021) 'Household debt and Covid', Bank of England Quarterly Bulleting, 2021 Q2

Haskel, J, (2021), 'Will the pandemic "scar" the economy?', Speech at online webinar at the University of Liverpool Management School, 19 July 2021.
Lenoël, C. and Young, G. (2021) 'Modelling the impact of Covid-19 on the UK economy: an application of a disaggregated New-Keynesian model', forthcoming

Macqueen, R. (2021) 'Interest rate rises and Covid-19 government debts', NIESR UK Economic Outlook, Spring 2021, May.

Marioni, L. (2021) 'Will people go back to the office after the pandemic?', Economics Observatory, July

ONS, (2021), 'Impact of double deflation on labour productivity: 1997 to 2018 ', 28 June 2021.

Rossi, B. (2021) 'Identifying and estimating the effects of unconventional monetary policy: How to do it and what have we learned?', The Econometrics Journal 24:1

Tamberi, N. (2021) 'UK-EU trade and the TCA update: results up to April 2021', UK Trade Policy Observatory blog, 23 July

Van Ark, B., de Vries, K., and Erumban, A. (2020) 'How to not miss a productivity revival once again?'National Institute Economic Review, February 2021, pp. 9-24.

Van Ark, B. (2021), 'Outlook on Productivity in 2021', The Productivity Institute, May 18, 2021.

https://www.productivity.ac.uk/news/outlook-on-productivityfor-2021/ 


\section{Box A The simple arithmetic of inflation. Using "drop-in" and "drop-out" for exploring future short-run inflation scenarios.}

\section{By Huw Dixon ${ }^{1}$}

Inflation is reported and understood as an annual variable: it states the proportional growth of prices over the previous twelve months to the present. Inflation figures are published each month, with a month's lag. The June 2021 inflation data were published on 14th July 2021: CPI inflation was 2.5 per cent (CPIH 2.4 per cent), meaning that the general level of prices in June 2021 was 2.4 per cent (2.5 per cent) higher than in June 2020. Monthly inflation is also published, going back for over a year, giving the month-on-month inflation (mom), the proportionate growth of inflation between months: for example, the June 2021 mom inflation was 0.4 per cent, meaning prices in June were 0.4 per cent higher than in May 2021. The headline annual and the month-on-month inflation are linked by a simple approximation that works very well when inflation rates are low (as they are now).

\section{Annual Inflation $=$ Sum of monthly inflation for the last 12 months.}

Thus, the June 2021 headline inflation of 2.4 per cent equals the sum of mom inflation from July 2020 through to June 2021 (inclusive), giving us the twelve-monthly figure. The change in the headline annual rate as we move forward by one month has two elements: the new monthly inflation "drops in", the previous eleven months stay the same, and the thirteenth month "drops out". Thus, if we compare the CPI for June 2021 (2.4 per cent) with May 2021 (2.1 per cent), we see the monthly inflation for May-June 2021 drop in (0.5 per cent) and the old inflation for May-June 2020 ( 0.1 per cent) drop-out. Hence the change in inflation ( 0.4 per cent) equals the sum of the new inflation 0.5 per cent which drops in minus the old inflation 0.1 per cent which drops out.

This simple relationship means that in July 2021, we already know the inflation that will drop out month by month for the next eleven months until the May-June 2021 eventually drops out in June 2022. The rate of monthly inflation is highly variable: whilst it has a mean of 0.17 per cent (which equates to an annual inflation rate of 2 per cent), it can be much higher or lower in any single month (although most of the values are between 0.6 per cent and -0.2 per cent). We do not know how the inflation will drop in over the coming months. However, we can make some assumptions to construct simple future scenarios.

In the first scenario, we can simply assume a constant monthly drop-in rate equal to the long-run average of 0.17 per cent (the "medium" case). In addition to this we can look at a "high" scenario with drop-ins at 0.25 per cent (equivalent to annual inflation of 3 per cent) and a "low" scenario of 0.08 per cent (equivalent to 1 per cent annual inflation). This then gives us predicted paths of inflation from June 2021 to June 2022, which reflect the known "drop outs" over this period (sometimes called "base effects"). If we do this, then we get the path of inflation depicted in Figure 1:

Figure 1 Scenario 1. A constant drop-in of new inflation

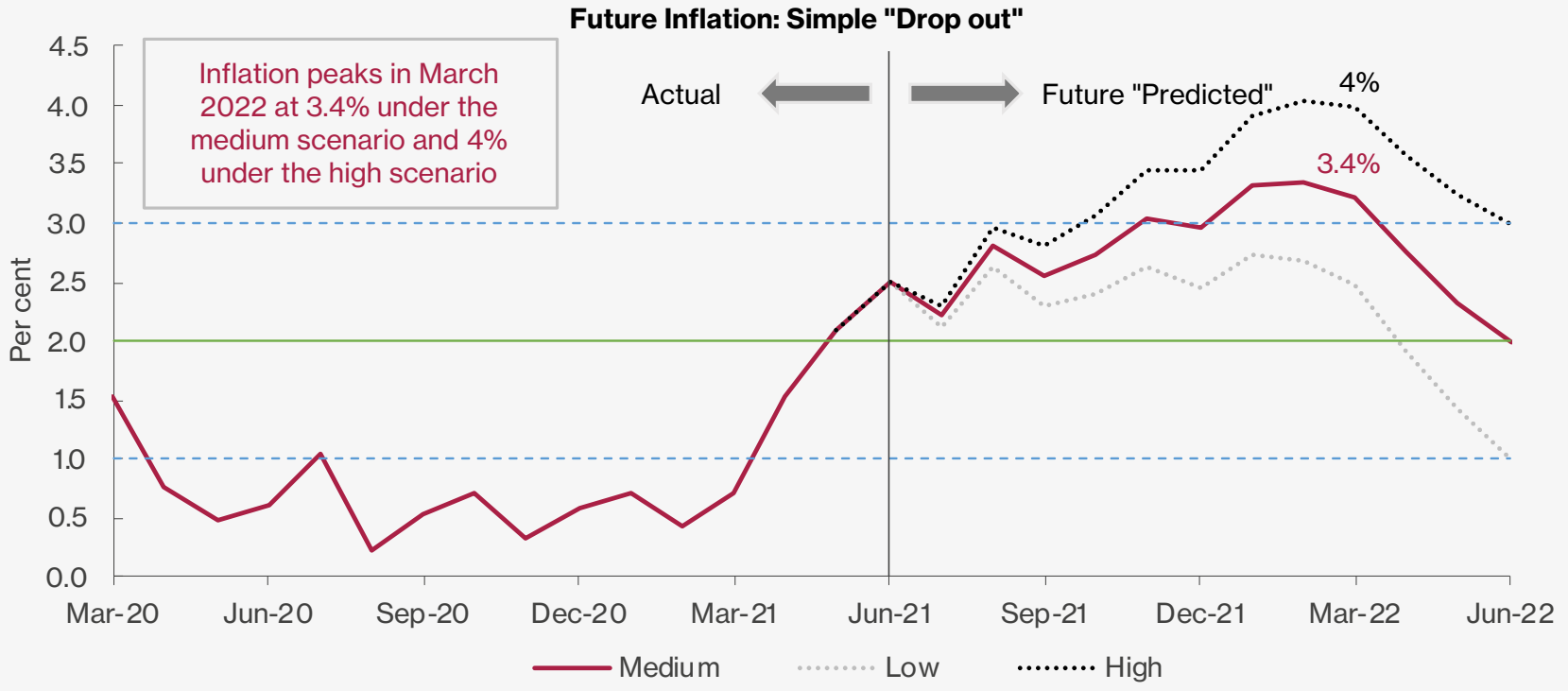

Source: Author calculations based on ONS CPI data

1 NIESR and Cardiff University. The author is grateful to Jagjit Chadha and Rory Macqueen for helpful comments and suggestions. 
In scenario 1, annual inflation peaks at 3.4 per cent in February with medium drop-ins and 4 per cent with high drop-ins. Inflation then declines rapidly (a mirror image of the surge in March-June 2020) despite constant mom inflation. Most economists would agree that the low drop-in scenario is unlikely in the coming months, but even this predicts a peak of 2.7 per cent annual inflation.

However, maybe we know more about the future, and can "adjust" the future drop-ins to reflect this. For example, we know that the VAT reduction introduced in July 2020 temporarily (a 5 per cent reduced rate of VAT relating to hospitality, hotel and holiday accommodation and admission to certain attractions) will be reversed in the coming months. There will be an increase from 5 per cent to 12.5 per cent in October 2021 ( 7.5 per cent pp up) and another from 12.5 per cent to 20 per cent from April 2022 (7.5 percentage points up). Assuming a CPI 'basket' share of up to 8.5 per cent and that these VAT increases are 100 per cent is passed on, this could imply up to 0.65 percentage points being added to mom inflation in these two months. This is surely an overestimate, since 100 per cent pass through is highly unlikely, but possible. However, we can add this as an additional "drop in" in the two relevant months of September 2021 and March 2022, depicted in Figure 2 for the three scenarios. Retaining our monthly drop-in assumptions from Scenario 1 otherwise, and concentrating on the medium and high cases, inflation peaks at 4.1-4.8 per cent in April 2022 and falls back to 2-3 per cent by April 2023.

\section{Figure 2 Scenario 2 VAT changes with full pass through}

Future Inflation with Simple Drop Out with VAT increases

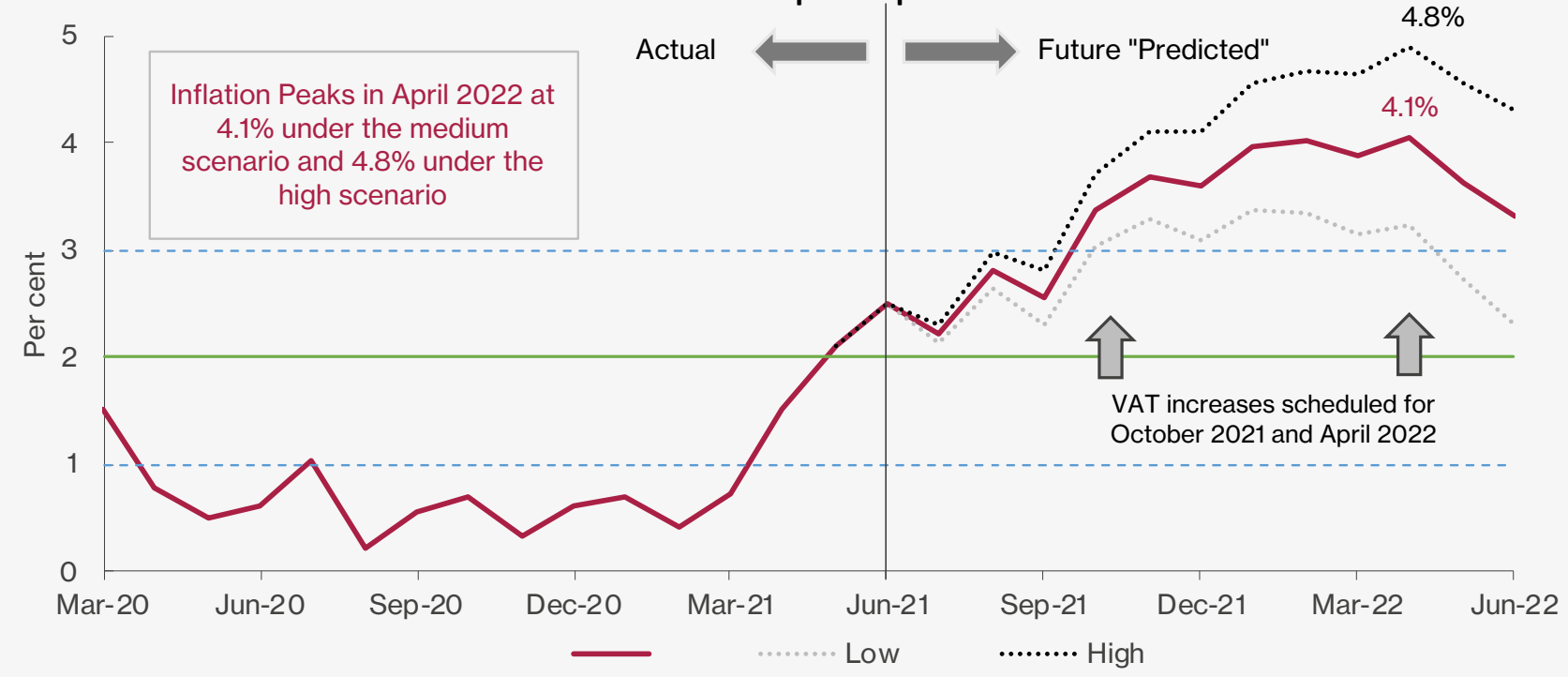

Source: Author calculations based on ONS CPI data

Of course, we may still know more about the future (for example likely changes to regulated prices such as energy) and can also allow for seasonality (rather than a constant drop-in rate have it varying with the usual "calendar month" effects). This simple 'hack' of representing annual inflation as the sum of the twelve-monthly values provides a simple way of getting this information into forecasts for the coming months.

How accurate is the approximation? It ignores "compounding". However, with monthly inflation at an average of 0.4 per cent or less (equivalent to 5 per cent annual inflation) this approximation works well to within one decimal place, which is the "precision" of the published inflation data. To be precise, because of rounding, you need to calculate the twelve monthly rates at full precision and then add them up before rounding. The ONS publishes the monthly rates to one decimal place, thus rounding each month individually. These rounding "errors" can accumulate, which is why the ONS annual rate might differ from the sum of the previous twelve monthly rates in its consumer price inflation release. 


\section{Box B The long and uncertain road to exiting Quantitative Easing}

By Cyrille Lenoël ${ }^{1}$

There is a rich literature on Quantitative Easing (QE) but less so on its unwinding. ${ }^{2}$ QE was initiated in 2001 in Japan, followed by the US in 2008 after the Global Financial Crisis, and there has been time to evaluate it, while there has not been any sustained unwinding of QE so far ${ }^{3}$. The only episode that approaches an unwinding of QE is the so-called 'Taper Tantrum' in the United States in 2013, when Treasury yields surged on the news that the Federal Reserve would be slowing down its purchases of bonds.

In this box, we survey the literature on $\mathrm{QE}$ and use the findings to discuss possible exit strategies. While there is little consensus among central bankers on the optimal exit strategy, what stands out is that the road to unwinding will probably be a long and uncertain one, and central banks may even keep large amount of government bonds permanently on their balance sheet.

\section{The channels of QE}

Quantitative easing is the process whereby a Central Bank (CB) purchases government or corporate bonds to stimulate the economy. Purchases are done in the secondary market in order to prevent 'monetary financing', which would be when the CB directly buys bonds issued by the Treasury (Macchiarelli and McMahon, 2020). The purchases tend to reduce the yields on the bonds and thus are intended to feed through to lower interest rates for households and businesses, stimulating economic activity in a similar way as a cut in the policy rate. In the UK, the Bank of England has announced the purchase of $£ 895$ billion worth of bonds between November 2009 and November 2020.

QE effects are generally decomposed in the economic literature into three channels: signalling, portfolio rebalancing and liquidity premium (Bailey et al., 2020). When the CB announces its intention to do QE, it also announces a timetable i.e. the total value of bonds to be purchased and over what period - usually several years. Because long rates are closely related to the expected path of short rates, such an announcement is seen by markets as a commitment to ease monetary policy for a significant period, and yields start declining at the announcement date, rather than when the CB actively starts purchasing bonds. This is the signalling channel.

On the other side of the bond transactions are sellers like money market funds or pension funds. These will generally reinvest the proceeds from their sale into other assets with higher yields like shares or properties. That process will in turn reduce the yields of other asset classes, making the households that hold these assets wealthier and able to spend more. This is the portfolio rebalancing channel. The academic literature models this channel by replacing the Efficient Market Hypothesis with assumptions of portfolio preferences so that different assets are imperfect substitutes on account of their non-pecuniary properties (Brainard and Tobin (1963), Andres et al. (2004), Chen et al. (2012) and Harrison (2012)), portfolio adjustment costs (Harrison, 2011, 2017), or preferred habitats, in which investors might demand certain assets for specific - perhaps regulatory - purposes (Vayanos and Vila, 2009, 2020).

The third channel is the liquidity premium. A bond investor will occasionally need to sell some of the bonds it holds and the risk that it may not find a willing buyer on time is called the liquidity premium. This liquidity premium is incorporated in the price of bonds. The fact that the CB becomes a willing buyer of a large quantities of bonds reduces the liquidity premium and therefore yields. The liquidity channel relies on the existence of a market or informational friction, which creates a role for central bank asset purchases in encouraging trading and reducing liquidity premia in a given market (Joyce et al., 2011; Haldane et al., 2016). By meeting the increased demand for safe and liquid assets by the banking sector and acting as a substitute for private sector collateral QE can also support the bank lending channel (Corrado et al., 2020). ${ }^{4}$

1 NIESR. The author is grateful to Jagjit Chadha, Hande Küçük, Corrado Macchiarelli and Rory Macqueen for helpful comments and suggestions.

2 See Chadha and Holly (2011) for an assessment of the effectiveness of QE and other unconventional monetary instruments used by central banks as a response to the GFC early on. Rossi (2021) provides a review of the recent empirical literature on the effects of QE.

3 Except for a brief episode in 2006 when the Bank of Japan reduced its holding of Japanese Government Bonds from ¥63.8 trillion in January 2006 to $¥ 49.2$ trillion in March 2007. Blinder (2010) describes this episode of monetary tightening as “curious” because it happened at a time when inflation was around 0 per cent.

4 The evidence on the bank lending channel is mixed because it interacts with other channels. Butt et al (2014) and Giansante et al. (2019) find no evidence of an increase in bank lending because of QE in the UK, but Kuang et al find (2020) and Kapoor and Peia (2021) find an effect in the US that depends on the level of reserves and type of assets that banks hold. 


\section{Diminishing returns?}

A difficult question for a CB initiating QE is how to evaluate the amount of bonds necessary to purchase in order to reduce yields to the target level. Is it possible that QE may suffer from diminishing returns whereby the central bank has to buy ever increasing quantities of bonds to have the same marginal effect.

Some studies have found diminishing effects of QE in later rounds - see for example Greenlaw et al. (2018) and Krishnamurthy and Vissing-Jorgensen (2011). One argument for diminishing returns is that the term premium - defined as the difference between the bond yield and the average expected value of future short-term interest rates over the life of the bond - may not decline too much without distorting markets. Via the portfolio rebalancing channel, QE reduces the term premium, which may then become negative. For example, with German Bund yields currently being negative, investors have the option of holding paper currency instead of buying Bunds, which may limit the effect of QE if the European Central Bank wants to increase its QE programme. However, NIESR's term premium estimate for Germany has been negative since May 2019, and it does not seem to have produced market dysfunctions in Germany or the Euro Area so far (National Institute Term Premium Tracker, June 2021)

On the other hand, additional QE bond purchases may remove bonds from investors who are more reluctant to sell them and thus who demand ever higher prices (and lower yields), suggesting the possibility of non-diminishing returns. In an empirical study, Ihrig et al. (2018) find persistent effect for all rounds of QE in the US.

There are differing views from policy makers about when QE is most effective. Bailey et al. (2020) and Vlieghe (2021) from the Bank of England have argued that QE is particularly effective in crisis times. As expressed by Gertjan Vlieghe " $[\mathrm{QE}]$ is a very powerful tool to lower yields when market functioning is poor, by significantly increasing aggregate liquidity through abundant reserves and signalling the willingness to offset shocks. But when market functioning is restored, and if long term yields already at very low levels with inflation expectations near the target, in my view the ability for QE to impart additional macro-economic stimulus is limited. In other words, the impact of QE is state-contingent" (Vlieghe, 2021). But Ben Bernanke, former Federal Reserve chair, argues that "the research rejects the notion that QE is only effective during periods of financial disruption. Instead, once market participants' expectations are accounted for, the impact of new purchase programs seems to have been more or less constant over time, independent of market functioning, the level of rates, or the size of the central bank balance sheet" (Bernanke, 2020).

\section{Quantitative estimates}

Figure B1 shows the minimum, maximum and median estimates from the literature of QE on 10-year yield reduction, normalized to purchases of 10 per cent of GDP, for the US, UK, Japan and Euro Area. The vast majority of the studies are for the US, but there are three for the UK and Euro Area each, and two for Japan. The studies unanimously conclude that QE lowers bond yields significantly, but the range of the estimates is quite wide. In the case of the UK, studies find that a $\mathrm{QE}$ expansion of 10 per cent of GDP reduces 10-year gilt yields by 46.5 basis points. Applying this estimate to the $£ 895$ billion of announced bond purchases by the Bank of England between 2009 and 2020 (or 47.5 per cent of average GDP), suggests a cumulative decline in 10year gilt yield of 2.2 percentage points. Over the same period, the yield declined from 3.8 per cent to 0.3 per cent, which suggests that 2.2 percentage points of the 3.5 percentage points decline can be attributed to the QE programme. ${ }^{5}$
Figure B.1 Literature estimates of effects of QE bond purchases on 10-year yields

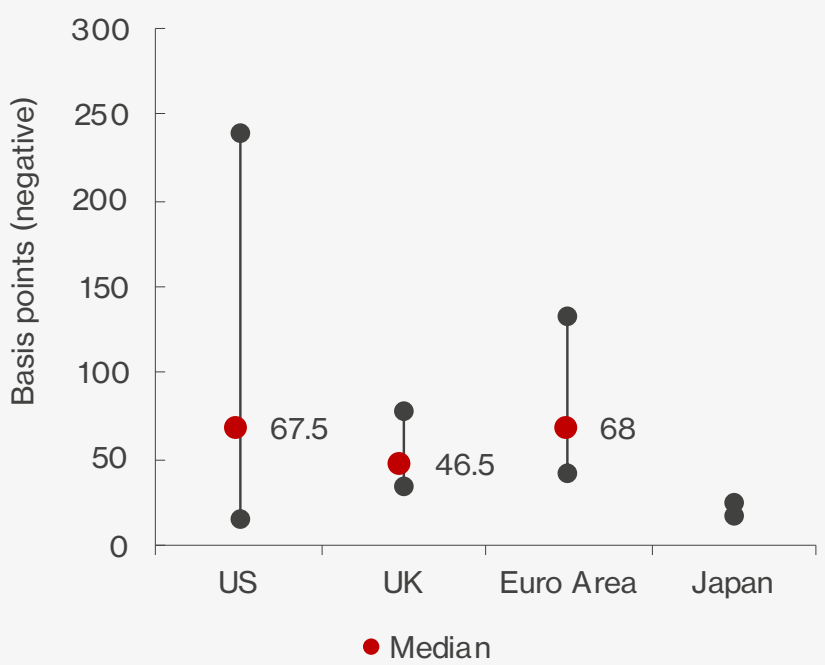

Note: Gagnon (2016) and author's calculations. Purchases are normalized to 10 percent of GDP.

5 The empirical evidence on the effects of QE on low frequency macroeconomic variables like inflation and output is less conclusive. See Rossi (2021) for an excellent review of this literature. 


\section{Exiting QE}

There are mainly two arguments for unwinding QE. The first one is to 'normalise' monetary policy so that there is more room to ease when the next negative shock hits the economy (Chadha, 2017). The second is that the recent rise in inflation in the UK may become more persistent if accompanied by a strong demand-side recovery and a rise in wages, and the Bank of England should consider tightening the overall policy stance as soon as next year. The two arguments are, of course, not mutually exclusive.

By reversing the channels of QE discussed above, one can get an idea of the likely effects of unwinding QE. The Taper Tantrum episode provides support for the idea that unwinding QE should be done over several years and in moderate steps, to prevent a strong market reaction. The greater uncertainty about the efficacy and channels of QE compared to the well-known effects of short-term policy rates, also argues for gradualism in unwinding it (Williams, 2013). An announcement to slow down asset purchases and start reducing the stock of holdings would be a strong signal to markets that the CB will tighten monetary policy and not look through a rise in inflation. Gradually reducing bond holdings will reduce liquidity in the government bond markets, and financial intermediaries need to be prepared to see one of the largest participants in this market step back. The portfolio rebalancing channel will lead to higher bond yields and term premia.

\section{The interaction between policy instruments}

The quantitative effects of entering and exiting QE may not be symmetrical because of the interaction with policy rates. QE was set up as a complementary easing instrument when policy rates were believed to be at the Zero Lower Bound (ZLB). But now that central banks have two main policy tools (policy rates and QE), it is not clear which should be used first when tightening monetary policy. In the case of the UK, if we assume the same median estimate of QE (46.5 basis points), then the hypothetical case of a full reversal of QE by the Bank of England could increase the 10 -year gilt from a current yield of 0.5 per cent to 2.7 per cent. However, there is considerable uncertainty around this estimate not only because of the uncertainty regarding how much the size of the balance sheet will be reduced but also because of the interaction with the policy rate. For example, if Bank Rate is raised first so that it is not at the ZLB, the impact of unwinding QE on yields may be lower per se. ${ }^{6}$

In its June 2018 meeting, the MPC set out its policy for unwinding QE: the Bank's balance sheet should be unwound "over a number of years at a gradual and predictable pace", allowing reserves to fall back to a level demanded by commercial banks as evidenced through participation in regular repo operations. The MPC also declared its preference for increasing Bank Rate first to $1 \frac{1}{2}$ per cent, before beginning to reduce its balance sheet. The threshold of 1.5 per cent, while somewhat arbitrary, was viewed as a level from which Bank Rate could be cut materially (or raised further) as necessary. This approach allows Bank Rate to be used as the primary instrument to set the stance of monetary policy in response to shocks in either direction, while a gradual and orderly balance sheet unwind continues. Broadbent (2018) justified this approach by reference to the fact that Bank Rate is a more flexible instrument, which can be adjusted more nimbly to shorter-term macroeconomic shocks, with more predictable effects.

While this policy has the merit of providing clear guidance, it has not been tested against alternative policies of normalisation: either to reduce the balance sheet before increasing Bank Rate, or to act simultaneously on the balance sheet and rates.

There are arguments for reducing the balance sheet first. QE may be more distorting to financial markets than the standard policy rate. By affecting both the short end of the yield curve (with the policy rate) and the long end (with $\mathrm{QE}$ ), the current policy stance tries to some extent to control the yield curve, which affects an important price signal for financial markets (Chadha, 2021). QE also has an impact on the profitability of some financial intermediaries like money market funds and banks, which may create financial instability and asset price bubbles. Darracq-Paries and Kuehl (2017) explain that frictions in financial markets make QE particularly effective at easing monetary policy at the ZLB via the term premium, and the corollary is that it is optimal to unwind QE before increasing policy rates in order to reduce the welfare costs of portfolio frictions.

6 Another complication regarding the exit from QE and a rise in interest rates relates to its possible impact on public finances given that the share of government debt held by the Bank of England is expected to reach some 40 per cent. The Treasury has received so far an indemnity of $£ 112$ billion from the Bank of England from marked-to-market gains associated to the gilts it holds, but is at risk of having to compensate the Bank if yields increase. See Macqueen (2021) and Allen (2021) for a detailed discussion. 
The recent rise in inflationary pressures requires central banks to start preparing the ground for a normalisation in monetary policy. Given the role of supply-side factors in pushing inflation up and continued uncertainties regarding the pandemic, communication around tapering asset purchases and policy rate normalisation will be crucial to avoid a significant tightening in financial conditions which risks the ongoing recovery.

\section{REFERENCES}

Allen, W.A. (2021), 'Managing the fiscal risk of higher interest rates', NIESR Policy Paper 25, March 2021.

Allen W.A., Chadha J.S. and Turner P. (2021), 'Quantitative Tightening: Protecting Monetary Policy from Fiscal Encroachment', National Institute of Economic and Social Research Policy Paper 027.

Andrés, J, López-Salido, J and Nelson, E (2004), 'Tobin's Imperfect Asset Substitution in Optimizing General Equilibrium', Journal of Money, Credit and Banking, 36(4), pages 665-90.

Bailey, A. J., Bridges, J., Harrison, R., Jones, J., \& Mankodi, A. (2020). 'The central bank balance sheet as a policy tool: Past, present and future'. Bank of England Working Paper No. 899.

Bernanke, B. S. (2020), The New Tools of Monetary Policy: American Economic Association Presidential Address. Brookings Institution, January, 4.

Blinder, A. S. (2010), 'Quantitative easing: entrance and exit strategies'. Federal Reserve Bank of St. Louis Review, 92(6), 465-479.

Brainard, W. C., \& Tobin, J. (1963), 'Financial intermediaries and the effectiveness of monetary controls'. American Economic Review, 53(2), 383-400.

Broadbent, B (2018), 'The history and future of QE', speech given at the Society of Professional Economists, London. 23 July

Butt, N., Churm, R., McMahon, M. F., Morotz, A., \& Schanz, J. F. (2014), 'QE and the bank lending channel in the United Kingdom', Bank of England Working Paper No. 511

Chadha, J. S (2017), 'Commentary: Interest rate normalisation', National Institute Economic Review No. 241, August 2017.

Chadha, J.S. (2021), Written evidence submitted to the Quantitative Easing Inquiry by Economic Affairs Committee https://committees.parliament.uk/ writtenevidence/36897/html/

Chadha, J.S., \& Holly, S. (2011). Interest rates, prices and liquidity. Cambridge University Press.

Chen, H, Cúrdia,V and Ferrero, A (2012), 'The macroeconomic effects of large-scale asset purchase programmes', The Economic Journal, Vol. 122, issue 564, pages F289-F315.

Corrado, L., Schuler, T. and Chadha, J.S. (2020), 'Bank Reserves and Broad Money in the Global Financial Crisis: A Quantitative Evaluation'. ECB Working Paper No. 20202463

Darracq-Paries, M and Kuehl, M (2017), 'The Optimal Conduct of Central Bank Asset Purchases', Deutsche Bundesbank Discussion Paper No. 22/2017.
Gagnon, J. (2016). 'Quantitative easing: An underappreciated success’. PIIE Policy Brief, 16.

Giansante, S., Fatouh, M., \& Ongena, S. (2019), 'Does quantitative easing boost bank lending to the real economy or cause other bank asset reallocation? The case of the UK', (August 18, 2019). Swiss Finance Institute Research Paper, No.19-72.

Greenlaw, D, Hamilton,J, Harris, J and West, K (2018), 'A Skeptical View of the Impact of the Fed's Balance Sheet', National Bureau of Economic Research Working Paper No. 24687.

Haldane, A, Roberts-Sklar, M, Wieladek, T and Young, C (2016), 'QE: the story so far', Bank of England Staff Working Paper No. 624

Harrison, R (2011), 'Asset purchase policies and portfolio balance effects: a DSGE analysis', in Chadha, J. S and Holly, S. eds Interest rates, prices and liquidity. Cambridge University Press.

Harrison, R (2012), 'Asset purchase policy at the effective lower bound for interest rates', Bank of England Working Paper No. 444.

Harrison (2017), 'Optimal quantitative easing', Bank of England StaffWorking Paper No. 678.

Ihrig, J, Klee, E, Li, C, Wei, M and Kachovec, J (2018), 'Expectations about the Federal Reserve's balance sheet and the term structure of interest rates', International Journal of Central Banking, Vol. 14(2), pages 341-90.

Joyce, M, Lasaosa, A, Stevens, I and Tong, M (2011), 'The Financial Market Impact of Quantitative Easing in the United Kingdom', International Journal of Central Banking, Vol. 7(3): pages 113-61.

Kapoor, S., \& Peia, O. (2021), 'The impact of quantitative easing on liquidity creation', Journal of Banking \& Finance, 122, 105998.

Krishnamurthy, A and Vissing-Jorgensen, A (2011), 'The Effects of Quantitative Easing on Interest Rates: Channels and Implications for Policy', Brookings Papers on Economic Activity 42 (Fall), pages 215-65.

Kuang, C., Yang, J. and Zhu, W. (2020), 'Quantitative Easing and Bank Lending: The Liquidity Channel', manuscript.

Macchiarelli, C. and McMahon, M. (2020), 'Quantitative easing and monetary financing: what's the difference?', Economics Observatory, 27 May 2020.

Macqueen, R. (2021), 'Interest rate rises and Covid-19 government debts', National Institute UK Economic Outlook, Spring 2021.

National Institute Term Premium Tracker, June 2021 available at https://www.niesr.ac.uk/sites/default/files/ files/NIESR $\%$ 20Quarterly $\% 20$ Term $\% 20$ Premium $\% 20$ Tracker\%20No_1\%20-\%20Full\%20Document.pdf 
Rossi, B, (2021), 'Identifying and estimating the effects of unconventional monetary policy: How to do it and what have we learned?', The Econometrics Journal 24:1

Vayanos, D and Vila, J (2009), 'A Preferred-Habitat Model of the Term Structure of Interest Rates', National Bureau of Economic Research Working Paper No. 15487.

Vayanos, D and Vila, J (2020), 'A preferred-habitat model of the term structure of interest rates', mimeo, London School of Economics.

Vlieghe, G. (2021) Speech at the University of Bath, on Thursday 27 May 2021

Williams, J (2013), 'A Defense of Moderation in Monetary Policy', Journal of Macroeconomics No. 38, December, pages $137-50$. 


\section{Box C Firm indebtedness and risks to investment}

By Issam Samiri ${ }^{1}$

This box provides an outlook on the indebtedness of UK firms and its implications for their ability to hire and invest.

\section{Corporate indebtedness following the Global Financial Crisis: A moderate deleveraging cycle}

The indebtedness of the non-financial corporate sector in the UK increased in the years leading to the Global Financial Crisis (GFC). UK non-financial corporations started a slow-paced deleveraging process following the GFC, with the debt to GDP ratio falling from its peak of 92 per cent in 2009 to 72 per cent in 2019. Non-financial corporate indebtedness decreased in the UK more than in other comparable advanced economies in the years following the GFC (Table 1). ${ }^{2}$ This is partly a reflection of the larger increase in non-financial corporate sector debt in the decade leading up to the GFC and the economic effects of the GFC. Debt service ratios (DSR), defined as the ratio of debt service cost over net operating income, also decreased in the UK in the years following the GFC, as shown in Figure 2. This decrease is a result of the moderation in debt growth and a much lower interest rate environment maintained by the central bank.

Table 1 Change in total credit to private non-financial corporations (per cent of GDP) in the United Kingdom and other G7 economies

\begin{tabular}{lcc}
\hline & Between 1998 and 2008 & Between 2008 and 2019 \\
\hline Australia & 19.4 & -10.3 \\
Canada & 1.4 & 28.2 \\
France & 20.8 & 31.9 \\
Germany & 3.8 & -4.7 \\
Italy & 27.9 & -9.5 \\
UK & 31.3 & -19.6 \\
US & 12.6 & 3.2 \\
\hline
\end{tabular}

Source: Bank of International Settlements (BIS) total credit statistics, author's calculations

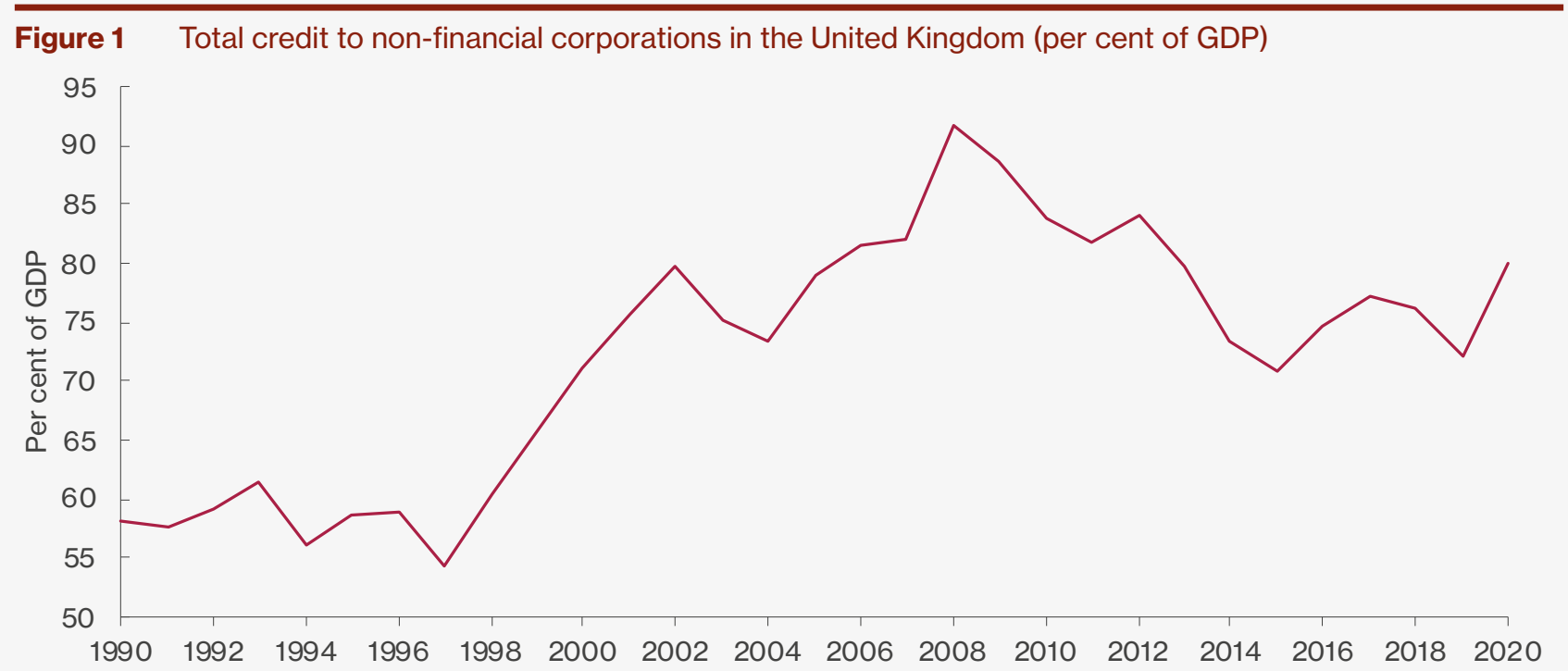

Source: Bank of International Settlements total (BIS) total credit statistics

1 NIESR. The author is grateful to Jagjit Chadha, Hande Küçük, Barry Naisbitt and Rory Macqueen for helpful comments and suggestions. .

2 See Naisbitt (2020) for more on the global vulnerability from debt in the coronavirus crisis. 
Figure 2 Debt service ratios (DSR) of non-financial corporations in the UK (per cent)

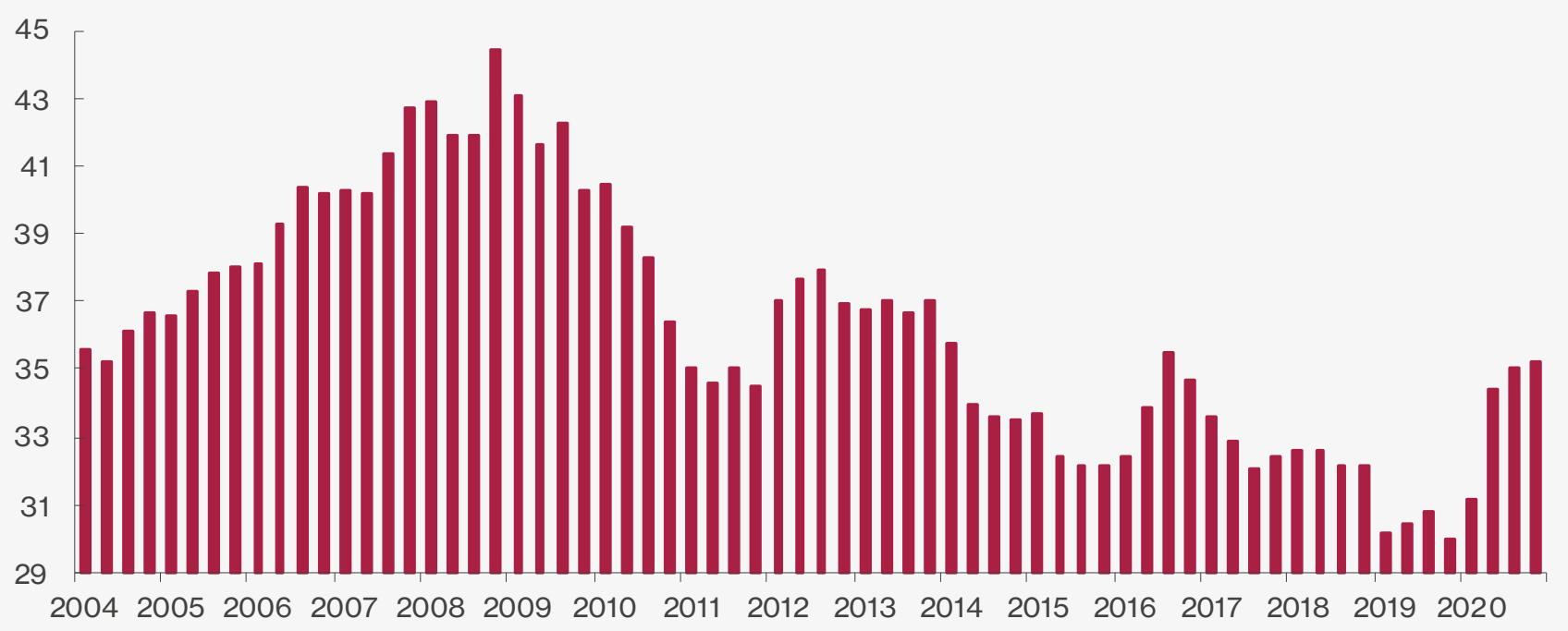

Source: Bank of International Settlements (BIS) total credit statistics

The pandemic and business indebtedness in the UK: More debt overall, more so for smaller businesses

Although firms' indebtedness has decreased since the GFC, corporate debt remained relatively high in historic terms in the years leading up to the pandemic (Figure 1). When the pandemic struck, the need to close the cashflow gap created by the pandemic-related economic disruption led to further demand for debt.

While $£ 75.5$ billion of net financing was raised by the UK's private non-financial corporations between March 2020 and May 2021 (Table 2), approximately $£ 75$ billion was raised through the government Covid-19 lending schemes. ${ }^{3}$ The UK government offered three loan packages to help UK firms weather the pandemic induced economic disruption: the Coronavirus Business Interruption Loan Scheme (CBILS), the Coronavirus Large Business Interruption Loan Scheme (CLBILS) and the Bounce Back Loan Scheme (BBLS). The CBILS was designed to provide financial support to smaller businesses, with loans of less than $£ 5$ million, while the CLBILS was dedicated to larger businesses with a turnover of more than $£ 45$ million by providing loans of up to $£ 200$ million. The BBLS was dedicated to provide businesses with readily available liquidity up to $£ 50,000$. These loan schemes were all issued by a selection of lenders with a full government-backed guarantee for the CBILS and BBLS loans and partial government-backed guarantee (80 per cent) for the CLBILS loans. They came to an end in March 2021. Of the £75 billion borrowed through these schemes, only $£ 5.6$ billion was borrowed by larger businesses through the CLBILS. A further Recovery Loan Scheme (RLS) opened to applications on 6th April 2021. This scheme provides financial support of up to $£ 10$ million to businesses across the UK to help them recover and grow following the pandemic. For loan facilities above $£ 250,000$, the RLS provides lenders with up to 20 per cent protection of outstanding balances after the proceeds of business assets have been applied.

Table 2 Net financing raised by the UK's private non-financial corporations through various instruments from March 2020 to May 2021 (in £ millions)

\begin{tabular}{lc}
\hline Net commercial paper issuance & -4284 \\
Net bond issuance & 23409 \\
Net shares issuance & 28338 \\
Net loan issuance & 28033 \\
Net total financing & 75496 \\
\hline
\end{tabular}

Source: Bank of England, author's calculations.

3 British Business Bank figures. 
One feature of business borrowing during Covid has been the rapid increase in borrowing by small and medium enterprises (SMEs). Average monthly net bank lending to SMEs between January and October 2020 was forty times higher than the 2016-2019 period average. ${ }^{4}$ The indebtedness of smaller firms, which tend to be concentrated in the sectors most affected by public health measures, has increased relative to larger firms. ${ }^{5}$ This increase in debt might adversely affect the future ability of SMEs to raise external finance and reduce hiring and investment.

Debt service ratios are increasing but remain moderate by historical standards in the corporate sector as of the end of 2020 (Figure 2). Given the higher overall indebtedness of the corporate sector and the effect of the Covid-19 economic disruption on firms' revenues, moderate debt service ratios are mainly attributable to the low interest rate environment maintained by a very accommodative monetary policy and a healthy appetite for risk from investors. These moderate debt service ratios mitigate the effects of increased indebtedness. Nevertheless, the relief provided by the current low interest rates is dependent on an accommodative monetary policy and the current appetite for risk that maintains narrow risk premia relative to historical standards. Debt service ratios can quickly deteriorate if UK firms decide to rollover their current debt levels at higher borrowing rates in the future.

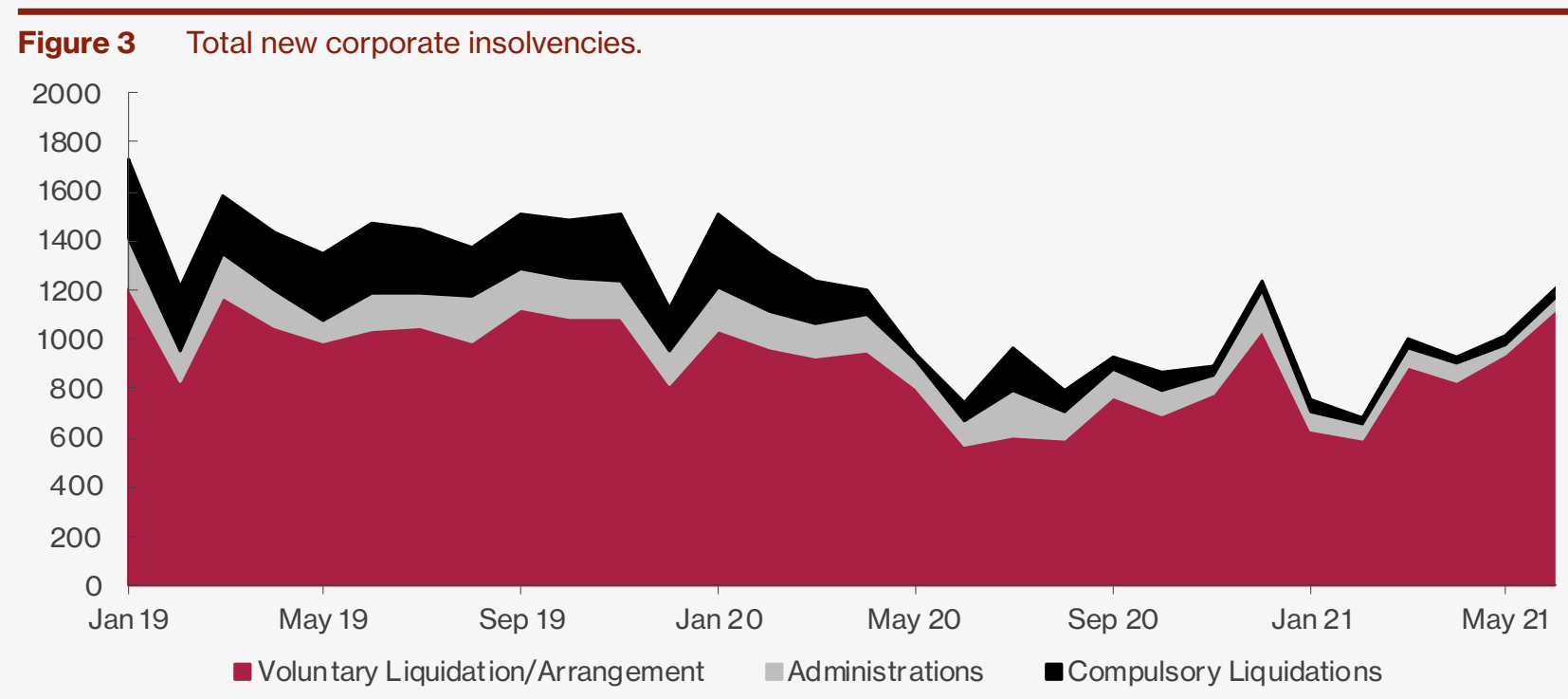

Source: Insolvency Service Official Statistics - June 2021, UK Insolvency Service

\section{Default rates and the cost of credit: A diverging landscape}

While rates of new corporate insolvencies remained subdued in 2020, they have picked up in 2021 (Figure 3). UK lenders reported that default rates on corporate loans increased for SMEs in the first half of 2021 while they remained stable for large corporates (Bank of England Credit Conditions Survey, 2021 Q2). This trend of higher

Table 3 Proportion of SMEs in distress (either arrears or default on pre-existing loans) by sector, between January 2020 and January 2021 (per cent).

\begin{tabular}{lrr}
\hline Sector & January 2020 & January 2021 \\
\hline Agriculture & 1.6 & 2.0 \\
Real Estate & 2.0 & 2.9 \\
Other & 3.5 & 5.3 \\
Transport \& Storage & 4.3 & 7.9 \\
Accommodation \& Food & 7.4 & 11.9 \\
\hline
\end{tabular}

Source: Bank of England Financial Stability Report - July 2021.

4 Financial Stability Report, Bank of England, December 2020.

5 Financial Stability Report, Bank of England, December 2020. 
default rates among SMEs looks likely to continue, as the proportion of SMEs in distress increases (Table 3). Reflecting these realities, the Bank of England Credit Conditions Survey reports that spreads on corporate loan lending to SMEs widened in the first half of 2021 while spreads on loans to larger corporates narrowed in the same period.

The picture emerging from the corporate bond market confirms the trends in the loan market. Better-rated corporates can issue bonds at increasingly lower yields relative to their worse rated peers. Golan (2020) reports that the ratio of BBB-rated to A-rated bond yields widened from 1.2x at the start of 2020 to around 1.45x by September 2020. This corroborates a corporate debt picture of a diverging ability to raise financing within the UK's corporate sector.

Lenders foresee a divergence in the credit quality of smaller and larger firms, with smaller businesses expected to witness higher default rates than larger firms. Moreover, capital markets imply a divergence in the credit quality of rated corporates, with better rated corporates expected to suffer lower default rates. This is reflected in the price of risk, as larger/better rated firms have been accessing credit with increasingly favourable terms relative to their smaller/worse rated counterparts.

\section{Debt overhang and risks to business investment and hiring}

At the start of the pandemic, UK firms were carrying relatively high debt levels by historical standards, with a debt to GDP ratio close to 70 per cent. These levels of indebtedness have increased further since the outbreak of the pandemic to reach 80 per cent by the end of 2020. In addition, smaller firms have increased their indebtedness more relative to larger corporate entities.

Government support helped UK firms remain in business and maintain some of their investments during the pandemic period (Jibril, Roper and Hart, 2021). Nonetheless, a debt overhang can hinder future investment by firms. If the current trends of increasing debt service ratios continue, less of the firms' cashflows can be dedicated to investments and hiring. In addition, high leverage can increase the risk perceived by investors bringing new capital to the firm, thus increasing the firms' financing rates and crowding out new investment opportunities with a positive net present value (Krugman, 1988).

The extent of the debt overhang from the build-up of debt in the years before the GFC is one explanation for low business investment in the period that followed the GFC. Kalemli-Ozcan, Laeven, \& Moreno (2018) and Barbiero, Popov, \& Wolski (2020) show that the negative effect of excessive leverage on investment by European firms (including UK firms) in the post-GFC period was both sizeable and persistent. ${ }^{6}$

The increased level of indebtedness of UK firms that has resulted from the experience of the pandemic might adversely affect the ability of UK businesses to invest and hire over the next few years. This could especially be the case for SMEs that have accumulated relatively more debt than larger corporates since the start of the pandemic.

\section{REFERENCES}

Baker, S. R. \& Bloom, N. (2013). Does uncertainty reduce growth? Using disasters as natural experiments. National Bureau of Economic Research.

Barbiero, F., Popov, A., \& Wolski, M. (2020). Debt overhang, global growth opportunities, and investment. Journal of Banking and Finance.

Demmou, L., Calligaris, S., Franco, G., Dlugosch, D., McGowan, M., \& Sakha, S. (2021). Insolvency and debt overhang following the Covid-19 outbreak: Assessment of risks and policy responses. OECD.

Golan, Jonathan;. (2020). Why we see a golden opportunity in corporate bonds. Retrieved from Schroders.com: https://www.schroders.com/en/gr/professional-investor/ insights/markets/why-we-see-a-golden-opportunity-in-ukcorporate-bonds/
Jibril, H., Roper S. \& Hart, M. (2021). Covid-19, business support and SME productivity in the UK. The Productivity Institute.

Kalemli-Ozcan, S., Laeven, L., \& Moreno, D. (2018). Debt overhang, rollover risk, and corporate investment. National Bureau of Economic Research.

Krugman, P. (1988). Financing vs. forgiving a debt overhang. Journal of Development Economics, 253-268.

Naisbitt, B. (2020). Vulnerability from debt in the Coronavirus crisis. NIESR Policy Paper, 020.

6 Other explanations for low investment in the post-GFC period include higher levels of uncertainty (Baker and Bloom 2013). 


\section{Box D Foreign aid makes good macroeconomic sense}

\section{By Dawn Holland ${ }^{1}$ and Dirk Willem te Velde ${ }^{2}$}

On 25 November 2020, the UK government took the decision ${ }^{3}$ to reduce the budget for foreign aid from 0.7 to 0.5 per cent of gross national income (GNI) in 2021. On 13 July 2021, Parliament voted in favour of maintaining these cuts, following the Chancellor's Statement ${ }^{4}$. This reduces the amount of aid available in 2021 by approximately $£ 4.5$ billion compared to what otherwise would have been the case. The announcement does not meet commitments in the main party election manifestos. Nor does it meet targets set in the 2015 International Development Act (although this Act allows for deviations in a single calendar year under certain fiscal circumstances). A UN resolution adopted in 1970 established the Official Development Assistance target of 0.7 per cent of donor countries' GNI. Fifty years later, the UK was one of just six countries that had achieved this target, alongside Germany, Denmark, Luxembourg, Norway and Sweden.

A $£ 4.5$ billion cut represents a small saving to the UK in the short term $(0.4$ per cent of planned total managed public expenditure of $£ 1,053$ billion in 2021). The bulk of this will fall on UK bilateral aid. Figure 1 illustrates UK bilateral aid flows in 2019 relative to the size of GDP in the recipient countries. These flows constitute a crucial source of finance in countries with limited access to international capital markets, and where extreme poverty rates tend to exceed 30 per cent. For example, a 30 per cent "cut" in UK aid to fragile countries such as South Sudan or Somalia would leave a hole in the countries' financial resources in excess of 1 per cent of GDP. Estimates by Miller and Roger (2021) suggest that UK bilateral aid to Ethiopia will be halved in 2021, an amount worth a quarter of a percentage point of Ethiopian GDP. Devex is tracking reports by aid agencies and other sources on the impact of UK aid cuts ${ }^{5}$, which have reported significant budget cuts in many other poor countries, including Bangladesh, Central African Republic, Myanmar, Nigeria, South Sudan, Somalia and Yemen. This will pose a substantial cost in these aid recipient countries.

Mitchell, Hughes and Ritchie (2021) estimate that, based on the Government's reported estimates of aid results over the period of 2015-2020, a cut in UK foreign aid of this magnitude could prevent 5.3 million children a year from being immunised against basic diseases, at a cost of 100,000 lives each year, and 4.5 million children a year may lose out on a decent education. The United Nations Development Programme has issued a Statement on UK funding cuts $^{6}$, stating that preventing the UK cuts to their organisation alone could have helped 1.2 million people to have better access to basic services; 350,000 people in crisis-affected countries to get a job; 280,000 people to gain access to justice; and 23 million hectares of land and marine habitats to be protected, improved or restored.

The aid cut fails to take into account macroeconomic spillover effects. Holland and te Velde (2012) simulated the effects of aid on both donor and recipient countries using the NiGEM model. They modelled the empirical effects of aid on growth and productivity by applying historical social rates of return from infrastructure spending (Briceño-Garmendia, Estache, and Shafik, 2004) and econometric estimations of the effects of Aid for Trade on reducing trade costs (Cali and teVelde, 2011). The scenarios suggested that an increase in aid that raises growth and productivity in recipient countries - for example, when directed towards infrastructure investment and reducing trade costs - has positive spillover effects on the rest of the world, by reducing consumer prices and expanding the volume of trade, including in those countries providing aid. In short, aid at this kind of level tends to pay for itself. A survey of the literature on aid studies supports the positive relationship between development aid and economic growth (Arndt, Jones and Tarp, 2016), although weak institutions and poor governance in recipient countries may limit the potential returns from development assistance (Bräutigam and Knack, 2004).

The UK benefits directly from external aid through the creation of UK-based jobs, through higher levels of exports and through cheaper imports from aid recipient countries. Mendez-Parra and te Velde (2017) estimate that UK bilateral aid provided 12,000 jobs in 2014 through aid-trade linkages (without tying aid). Cutting aid directly reduces the number of UK-based jobs. The UK also derives indirect benefits from its external aid through the provision of global public goods such as addressing climate change, conflict resolution, or supporting the timely vaccination of the global population.

\footnotetext{
NIESR.

Overseas Development Institute. The authors are grateful to Jagiit Chadha and Barry Naisbitt for helpful comments and suggestions. https://www.gov.uk/government/publications/spending-review-2020-documents/spending-review-2020 
Interest rates are currently at historic lows in the UK, and despite rising levels of aggregate debt, UK debt interest payments as a per cent of total government spending are also historically low. By contrast, countries such as Lebanon, Somalia, Syria, Yemen and Zimbabwe are effectively shut out of capital markets, or face a borrowing premium in excess of 10 per cent. At the same time, investment needs in the poorest countries are high. With support from sound institutions and leadership, this investment can yield high domestic and global returns when targeted well, for example towards trade facilitation, physical and social infrastructure, and human capital accumulation.

Finally, the fiscal tests established by the Government ${ }^{7}$ to determine when it will revert to the aid commitments set in the 2015 International Development Act deviate markedly from the standard principles governing HM Treasury's fiscal policy. The tests fall short of recommendations for a new fiscal framework discussed in Chadha, Küçük and Pabst (2021). The tests make spending on a specific category conditional on both attaining a current budget surplus and a decline in the aggregate stock of debt. The UK's fiscal policy has traditionally avoided hypothecation and direct earmarking. The specific tests have been met only 5 times since 1990, and according to current forecasts may only be met by 2025-6 at best. This would imply a reduction of UK aid by $£ 25$ billion compared to maintaining an aid budget of 0.7 per cent of GNI. The tests also ignore the fact that aid flows should often be viewed as investment rather than current spending. The returns from this investment, as described above, have the potential to reduce the debt stock. In other words, cutting expenditure on aid may, in fact, delay the stabilisation of public finances in the UK.

In conclusion, the recently announced cuts in UK aid provide negligible direct savings for the UK, place immediate burdens on poor countries, eliminate UK-based jobs and other positive spillover effects from external aid, and set a poor precedent for macroeconomic policy. These decisions to cut aid should be reconsidered and take into account the available macroeconomic evidence.

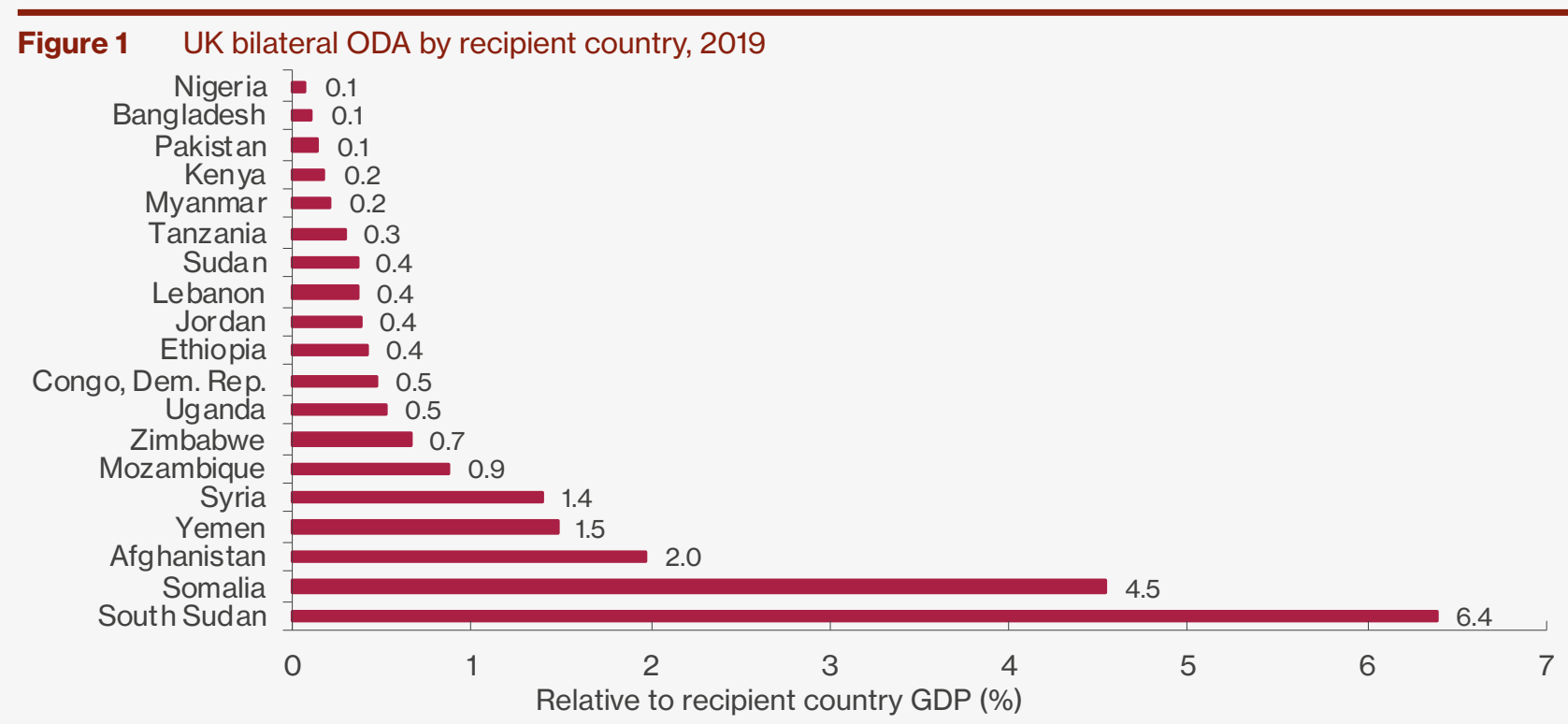

Source: Derived from Foreign, Commonwealth \& Development Office, Statistics on International Development, September 2020; IMF World Economic Outlook Database, April 2021; United Nations National Accounts Main Aggregates Database, December 2020.

\section{REFERENCES}

Arndt, C., Jones, S. and Tarp, F. (2016), 'What Is the Aggregate Economic Rate of Return to Foreign Aid?', The World Bank Economic Review, Volume 30, Issue 3, October 2016, Pages 446-474, https://doi.org/10.1093/wber/lhv033
Bräutigam, D., and Knack, S. (2004), 'Foreign Aid, Institutions, and Governance in Sub-Saharan Africa,' Economic Development and Cultural Change, 52(2), 255285. doi: $10.1086 / 380592$ 
Briceño-Garmendia, C., A. Estache A. and N. Shafik (2004), 'Infrastructure Services in Developing Countries: Access, Quality, Costs, and Policy Reform', World Bank Policy Research Paper No. 3468

Cali, M. and D.W. te Velde (2011), 'Does aid for trade really improve trade performance?’, World Development

Chadha, J., Küçük, H. and A. Pabst (Eds), (2021), Designing a new fiscal framework: Understanding and confronting uncertainty, NIESR Occasional Paper LXI.

Holland, D. and D.W. te Velde (2012), 'The effects of EU aid on receiving and sending countries. A modelling approach, study for One', http://one.org.s3.amazonaws.com/pdfs/ The_effects_of_EU_aid_on_receiving_and_sending countries_Report.pdf

Mendez-Parra, M. and D.W. te Velde (2017), 'Aid, export and employment in the UK, ODI Briefing Note, 'https:// euagenda.eu/upload/publications/untitled-91177-ea.pdf

Miller, M. and L. Roger (2021), 'Piecing together changes to UK bilateral aid allocations', ODI. https://odi.org/en/ insights/piecing-together-changes-to-uk-bilateral-aidallocations/

Mitchell, I., Hughes, S. and E. Ritchie (2021), 'An Overview of the Impact of Proposed Cuts to UK Aid, CGD Notes', Jan 2021. https://www.cgdev.org/publication/overviewimpact-proposed-cuts-uk-aid 